\title{
Article \\ Petroleum Charging History of the Paleogene Sandstone Reservoirs in the Huangtong Sag of the Fushan Depression, South China Sea
}

\author{
Xin Wang ${ }^{1}$, Zhenghuan Lu ${ }^{2, *}$, Meijun Li ${ }^{1,3}{ }^{\mathbb{D}}$, Hao Guo ${ }^{2}$, Zhili Zhu ${ }^{4}$, Xiaohan Li ${ }^{2}$, Chengyu Yang ${ }^{1}$, Bang Zeng ${ }^{1}$, \\ Fangzheng Wang ${ }^{1}$ and Zichao Ran ${ }^{1}$
}

check for

updates

Citation: Wang, X.; Lu, Z.; Li, M.; Guo, H.; Zhu, Z.; Li, X.; Yang, C.; Zeng, B.; Wang, F.; Ran, Z. Petroleum Charging History of the Paleogene Sandstone Reservoirs in the Huangtong Sag of the Fushan Depression, South China Sea. Energies 2022, 15, 1374. https:// doi.org/10.3390/en15041374

Academic Editor: Alexei V. Milkov

Received: 27 December 2021

Accepted: 11 February 2022

Published: 14 February 2022

Publisher's Note: MDPI stays neutral with regard to jurisdictional claims in published maps and institutional affiliations.

Copyright: (C) 2022 by the authors. Licensee MDPI, Basel, Switzerland. This article is an open access article distributed under the terms and conditions of the Creative Commons Attribution (CC BY) license (https:// creativecommons.org/licenses/by/ $4.0 /)$.
1 The State Key Laboratory of Petroleum Resources and Prospecting, College of Geosciences, China University of Petroleum (Beijing), Beijing 102249, China; wangxin2021@student.cup.edu.cn (X.W.); meijunli@cup.edu.cn (M.L.); yangchengyu@cup.edu.cn (C.Y.); zb2020310008@student.cup.edu.cn (B.Z.); wangfangzheng@student.cup.edu.cn (F.W.); ranzichao@student.cup.edu.cn (Z.R.)

2 Southern Oil Exploration and Development Company, PetroChina, Haikou 570216, China; guohao1118@cnpc.com.cn (H.G.); lixiaohan01@cnpc.com.cn (X.L.)

3 Key Laboratory of Exploration Technologies for Oil and Gas Resources, Ministry of Education, College of Resources and Environment, Yangtze University, Wuhan 430100, China

4 Wuxi Branch of Exploration and Production Research Institute, Sinopec, Wuxi 214000, China; zhuzhili.syky@sinopec.com

* Correspondence: luzh01@cnpc.com.cn

\begin{abstract}
The Paleogene sandstone reservoir in the Huangtong Sag of the Fushan Depression is one of the most commercially prolific oil accumulations in the Beibuwan Basin, South China Sea. In this study, twenty-seven crude oil samples from four oilfields in the sag were geochemically analyzed and classified into three oil groups. Oils in the Meitai and Hongguang oilfields show similar geochemical characteristics, with relatively abundant $C_{30} 4 \alpha$-methyl-24-ethylcholestanes and low contents of oleanane and $\mathrm{C}_{19+20}$ tricyclic terpanes (TT), and therefore may be derived from the same source kitchen. Oils from the Yong'an oilfield have a greater proportion of oleanane and $\mathrm{C}_{19+20} \mathrm{TT}$ compounds. Oils from the Chaoyang oilfield have intermediate contents of these biomarkers and proportionate values of other related parameters. The unimodal distribution pattern of homogenization temperatures of fluid inclusions found in all the Paleogene reservoirs indicates a single episode of charging. Combining this understanding with the reconstruction of stratigraphy-burial and geothermal histories by 1-D basin modeling, the petroleum charging time was determined to be between 8-2 Ma (the end of the middle Miocene to the early Pliocene). Hydrocarbon migration orientation and charging pathways were traced using molecular indicators (4-/1-methyldibenzothiophene and 1-/4-methodibenzofuran). In the Chaoyang oilfield, the values of these geochemical parameters decreased with decreasing burial depth, indicating vertical oil migration along faults, which are plentiful in the sag. Sandstone bodies with deeper burial depths may therefore be the most promising exploration targets in the Chaoyang area. The Yong'an oils generally migrate from the northwest toward the southeast, suggesting that the source kitchen for the Yong'an oilfield is in the northwest. By similar inference, the hydrocarbon source kitchen for the Hongguang-Meitai area is likely to be on the north side of the Hongguang-Meitai area. By tracing these hydrocarbon charging pathways, the northwest of the Yong'an area and the northern part of the Hongguang-Meitai area are identified as the most promising areas for exploration.
\end{abstract}

Keywords: the Fushan Depression; South China Sea; oil group classification; oil charging history; oil migration direction

\section{Introduction}

The Fushan Depression, in the southeastern of the Beibuwan Basin, is a proven hydrocarbon-abundant province, with a yield of 400,000 tons per year [1]. The area has 
been under exploration for more than sixty years, and several major oil fields have been discovered [2,3]. The principal source rocks and reservoirs are in the Paleogene Liushagang Formation which consists of lacustrine and deltaic sediments [4-6]. The depression is divided into the Bailian and Huangtong sags by an oblique transfer zone. The geothermal evolution, oil-source correlation, hydrocarbon charging, and oil migration orientation of the Huachang-Bailian area, in the central and eastern parts of the depression, have been extensively discussed [1,7-16]. Two distinct petroleum systems have been distinguished in the Huachang-Bailian area on the basis of biomarker and organic carbon isotope compositions $[1,6]$. In a study of the geothermal history and homogenization temperatures of fluid inclusions in the area, Wang et al. (2016) proposed that the oblique transition zone has experienced only one episode of hydrocarbon charging, around the Middle Miocene to Pliocene, which corresponds to the main stage of the Dongsha Movement [6]. A number of geochemical parameters, related to alkyl dibenzothiophenes, alkyl dibenzofurans, benzo[b] naphthothiophenes, alkyl naphthalenes, phenanthrenes, etc., have been used to trace the oil filling pathways [9-16]. The oils in the Huachang Uplift mostly originate from the Bailian Sag, so the migration orientation is generally from northeast to southwest [6,9-16].

Previous studies have concentrated on the Huachang-Bailian area in the east of the Fushan Depression. The presence of the transfer zone in the central region has resulted in quite different geological conditions in the western and eastern areas and, due to its comparatively low degree of exploration, less research has been done in the western part, including the Huangtong Sag [4,5,17-19]. On the basis of differences in maturation levels and relative contents of oleanane, Lu et al. (2016) identified three types of crude oils in the Huangtong Sag and Li et al. (2007a and 2007b) concluded that the Paleogene sandstone reservoir in the Yong'an area of the Fushan Depression has also only been charged once, around the same geological time as the charging event in the Huachang-Bailian area $[2,3,20]$. However, the biomarker compositions of the different crude oils were not reported. Precise timings of hydrocarbon accumulation episodes and oil migration orientations have not yet been determined for any part of the Huangtong Sag.

This research aims to enhance oil-oil correlation and reveal the oil charging history in the Huangtong Sag. Studies on oil family classification can provide valuable information on petroleum migration in petroliferous basins. The fluid inclusion analysis in conjunction with the stratigraphic burial history and thermal history of the reservoirs can provide direct evidence regarding hydrocarbon charging stages. Determined the charging history are crucial to the prediction of potential source kitchen locations and identification of favorable exploration targets in the Huangtong Sag.

In this work, the oil-oil correlation was analyzed systematically based on the geochemical characteristics of oils in four oilfields (the Meitai, Hongguang, Chaoyang, and Yong'an). The timing of hydrocarbon charging of the Huangtong Sag is determined according to the homogenization temperatures of fluid inclusions and the stratigraphic burial and geothermal histories of the sag. Molecular markers are used to trace the oil charging orientation and channels. A comprehensive understanding of the oil-oil correlations and charging history of the study area is of great significance in improving understanding of the petroleum systems in this region and reducing risk in petroleum exploration.

\section{Geological Settings}

The Fushan Depression is a Mesozoic-Cenozoic depression located in the southeastern corner of the Beibuwan Basin with an area of about 29,200 $\mathrm{km}^{2}$ (Figure 1a). Its north area is controlled by the Changliu and Lingao Faults, and the south area overlaps on the Hainan Uplift $[4,21]$. The depression experienced multiple tectonic movements in the Paleogene, creating a complex geological structure consisting of three tectonic units: the north Chaoyang step-fault zone, the central Huangtong Sag, and the south slope zone (from north to south) (Figure 1b) $[5,17,22]$. The oblique transfer zone, above the Huachang uplift in the center of the depression, divides the depression into the Bailian Sag in the east and the Huangtong Sag in the west $[6,23]$. 

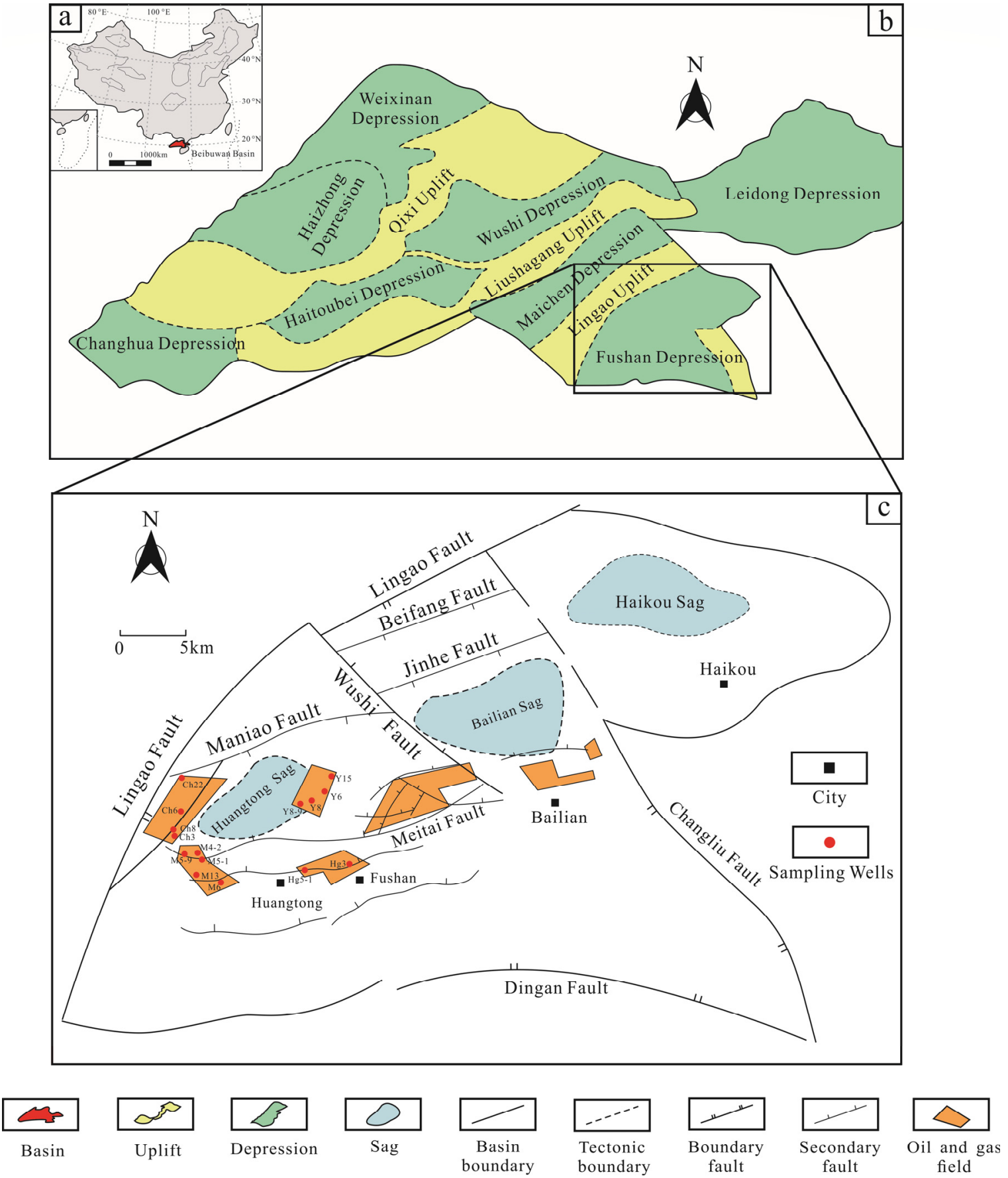

Figure 1. The schematic geological map of the Huangtong Sag and sample position. (a) Location of the Beibuwan Basin. (b) Location of the Fushan Depression. (c) Location of the sampling wells in the Fushan Depression.

The Shenhu, Zhuqiong, and Nanhai tectonic movements in the Paleogene respectively controlled the deposition of the Paleocene Changliu Formation (Ech), the Eocene Liushagang Formation (Els), and the Oligocene Weizhou Formation (Ewz). Ech and Ewz comprise fluvial facies and alluvial fan, while Els is predominantly lacustrine facies (Figure 2). Els serves as the major source and reservoir rocks in the sag and is divided into three members-Els $s_{3}, \mathrm{E} l_{s_{2}}$, and $\mathrm{E} l_{s_{1}}$ - which are all third-order sequences according to the sequence stratigraphic principles set out by Vail et al. (1997) [24] (Figure 2). Els $s_{1}$ and Els 3 are generally developed braided river delta, fan delta, and lacustrine mudstone. Els $s_{2}$ was deposited during the most substantial lacustrine transgression period, with deep and 
semi-deep lacustrine mudstones of great thickness which serve as the main source rocks for the Liushagang Formation.

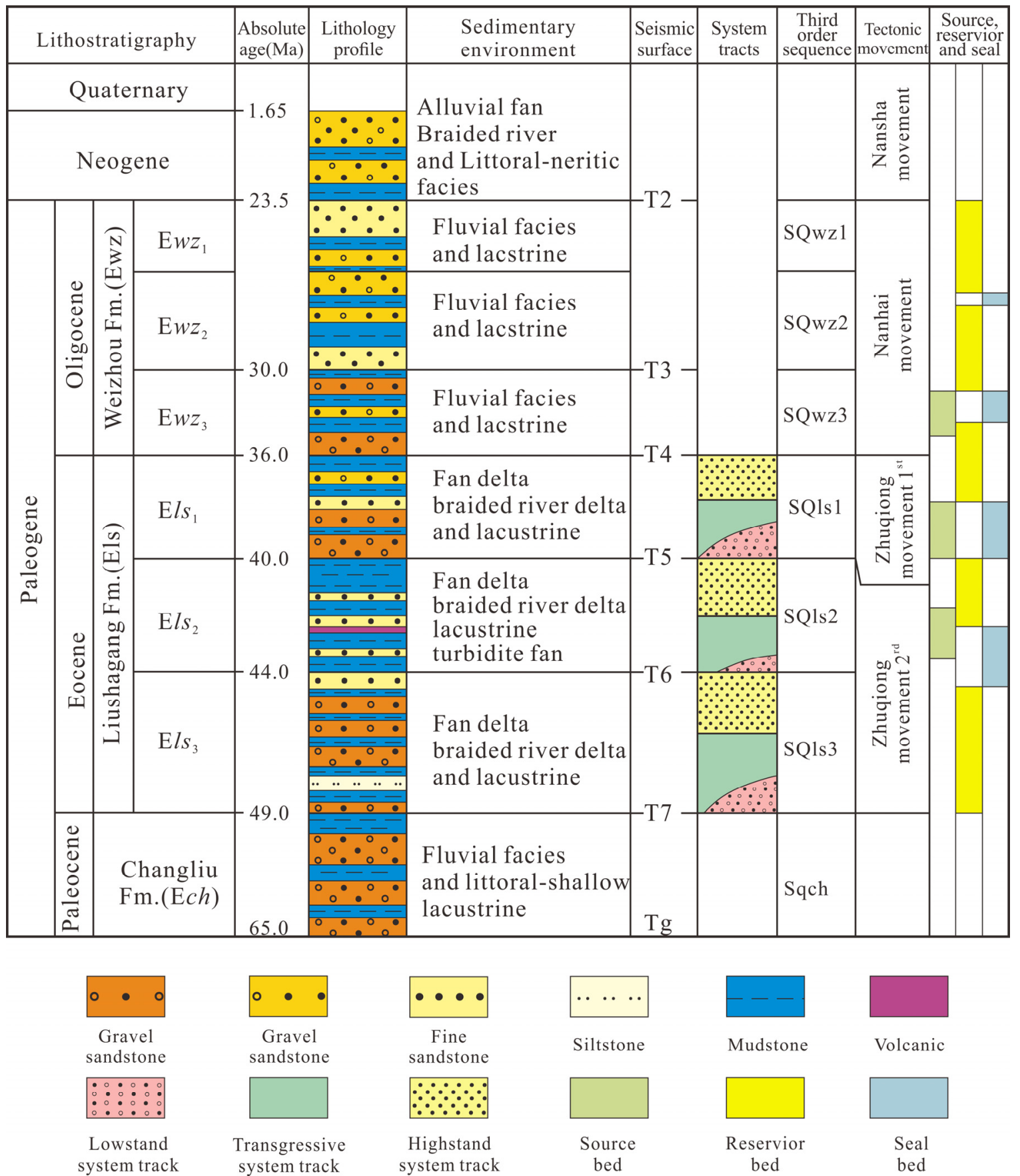

Figure 2. The Paleogene sedimentary sequence and stratigraphic framework of the Fushan sag, Beibuwan basin, Southern China Sea.

The primary exploration target is the area around the Huangtong sag, where the Meitai, Hongguang, Chaoyang, and Yong'an oilfields have been discovered. Els 3 provides the major reservoir for the Meitai and Hongguang areas. The crude oil in the Chaoyang and Yong'an oilfields is mostly in $\mathrm{E} \boldsymbol{s}_{1}$. 


\section{Samples and Methods}

A total of twenty-seven oil samples were collected from these four oilfields. All of the samples were deasphalted using n-hexane and the residues quantitatively separated into saturated, aromatic, and NSO fractions by liquid chromatography (alumina/silica gel columns, 2:3) with $30 \mathrm{~mL}$-hexane, $25 \mathrm{~mL}$ dichloromethane: n-hexane (2:1, v:v) and dichloromethane: methanol $(93: 7, v: v)$ as the eluents, respectively.

The saturated fraction was analyzed using an Agilent 6890 gas chromatographAgilent 5975i mass spectrometry system, using an HP-5MS fused silica capillary column $(30 \mathrm{~m} \times 0.25 \mathrm{~mm} \times 0.25 \mu \mathrm{m})$. The initial GC oven temperature was maintained at $50{ }^{\circ} \mathrm{C}$ for $1 \mathrm{~min}$, then increased at a rate of $20^{\circ} \mathrm{C} / \mathrm{min}$ up to $120^{\circ} \mathrm{C}$, further increased at $3{ }^{\circ} \mathrm{C} / \mathrm{min}$ to $310{ }^{\circ} \mathrm{C}$, then finally held at $310{ }^{\circ} \mathrm{C}$ for $25 \mathrm{~min}$. Helium, pumped at $1.0 \mathrm{~mL} / \mathrm{min}$, was used as the carrier gas for GC of the saturated and aromatic fractions. The chromatograph was run in electron impact (EI) mode, the ionization energy of the MS system was $70 \mathrm{eV}$, and the scanning range was $m / z$ 50-600.

Thirteen sandstone core samples from the $\mathrm{E} l_{s_{1}}$ and $\mathrm{E} l_{3}$ reservoirs were polished for fluid inclusion observation and homogenization temperature measurement. These oil sand samples were collected from wells M12A, Ch6, and Y11, which were distributed in Meitai, Chaoyang, and Yong'an oilfields, respectively.

Fluid inclusion observation was performed on the samples using a Leica polarizationfluorescence microscope with a fluorescence photometer (using UV excitation). Homogenization temperature measurements were carried out using the heating-freezing stage of a Linkham Model THMSG 600. The temperature was increased from $24{ }^{\circ} \mathrm{C}$ (room temperature) to homogenization temperature (Th) at $5{ }^{\circ} \mathrm{C} / \mathrm{min}$ and then held at Th for $1 \mathrm{~min}$ for temperature measurement. The measurement error was $\pm 1^{\circ} \mathrm{C}$. Since the Th of hydrocarbon inclusions is generally lower than the actual trapping temperatures, the homogenization temperatures of brine inclusions associated with the oil-bearing inclusions were also measured.

A total of 38 cores or rock cuttings from Y11, M12A, and Ch6 wells were sampled for vitrinite reflectance measurement. Polished blocks were made for all these samples. Vitrinite reflectance Ro (\%) was measured on each polished block by using a Leica Model MPV-SP microscopic photometer. The measured Ro (\%) profile was used to calibrate the reconstructed thermal history by basin modeling. The BasinMod-1D software was applied for the reconstruction of the burial and thermal history of Y11, M12A, and Ch6 wells. Data for modeling, i.e., stratigraphic data, eroded thickness, were provided by the Southern Oil Exploration and Development Company. The essential compaction mechanism considered in the simulation was mechanical compaction. In addition, Steady State Heat Flow models were used for the simulation of the thermal history.

\section{Results and Discussion}

\subsection{Organic Geochemical Characteristics of Oils in the Huangtong Sag}

\subsubsection{The Distribution of Normal Alkanes and Acyclic Isoprenoids}

$\mathrm{C}_{12}-\mathrm{C}_{35}$ normal alkanes were detected in all oil samples, with no obvious odd carbon preference, reflecting that all samples were mature oils (Figure 3). The pristane/phytane ratio $(\mathrm{Pr} / \mathrm{Ph})$ is widely used to indicate the depositional environment of source rocks and related crude oils [25]. All the samples in this study had relatively high contents of pristane relative to phytane, with ratios ranging from 3.36 to 4.43 (average 3.93) which suggests that the source rocks were deposited in an oxidizing environment. Similarly, in the cross-plot of dibenzothiophene/phenanthrene (DBT/Phen) to Pr/Ph (Figure 4), all the data points fell within the fluvial and deltaic zones, indicating predominantly oxidizing environmental conditions with terrigenous organic matter input. 

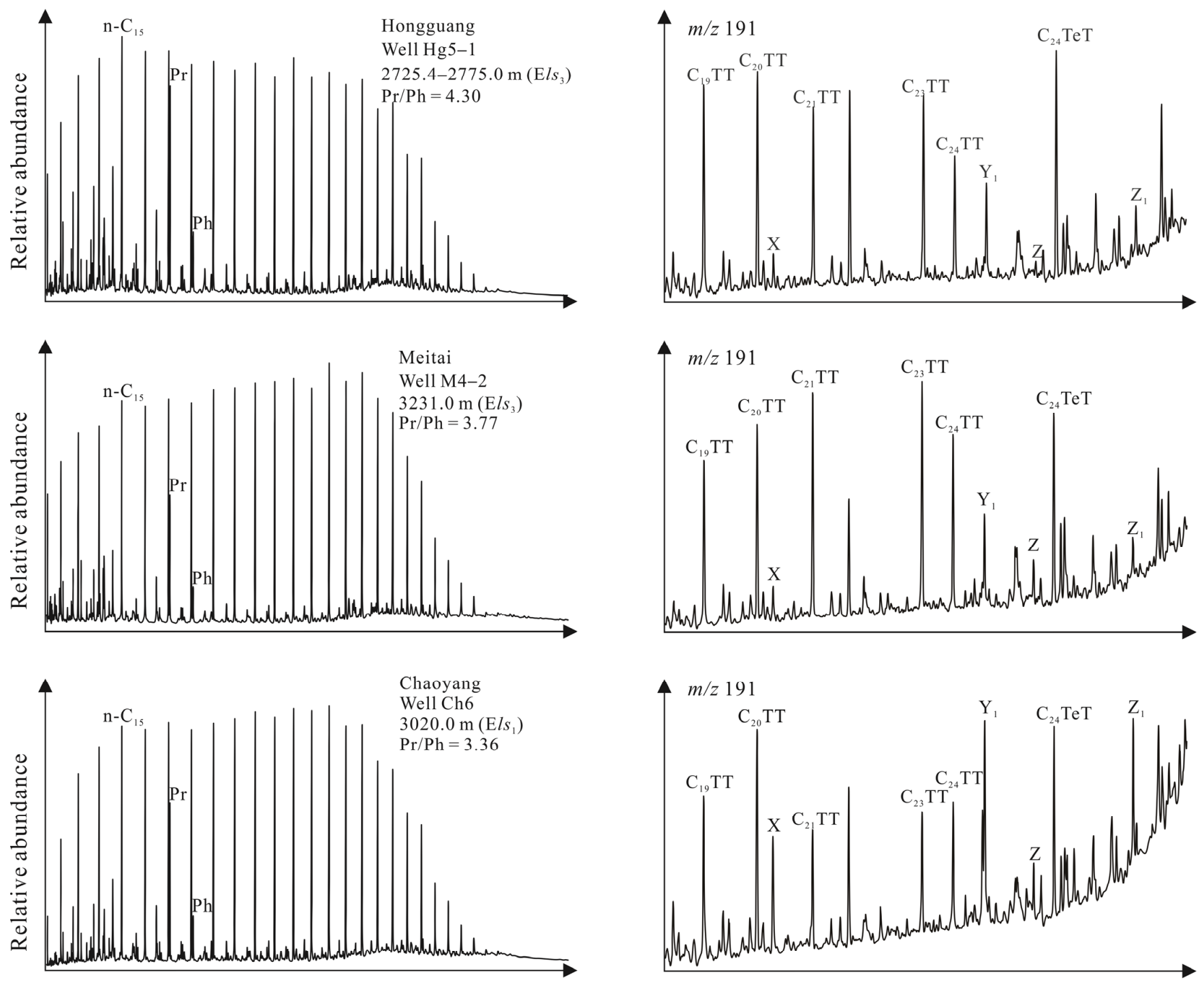

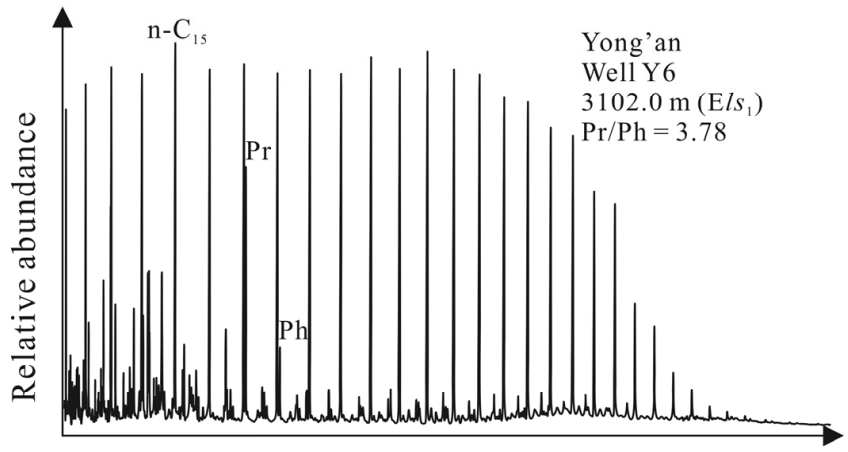

Relative retention time

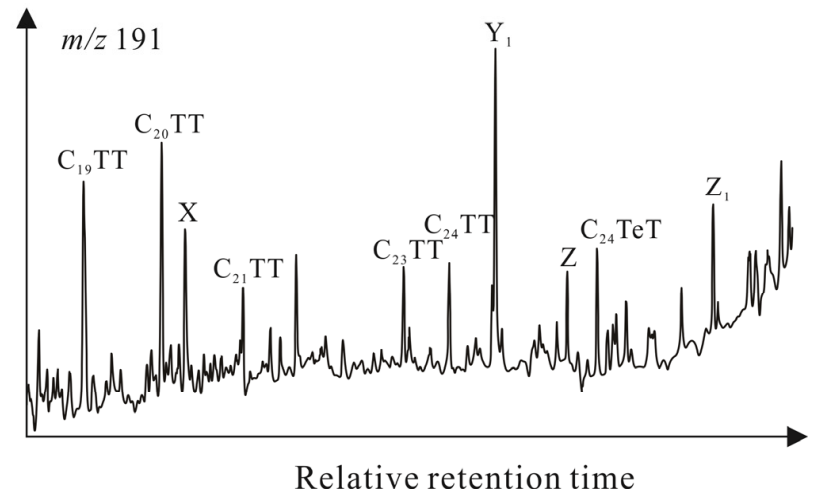

Figure 3. TIC and mass chromatograms $(m / z$ 191) showing the distribution of normal alkanes and tricyclic terpanes. Note: $\mathrm{Pr}=$ Pristane; $\mathrm{Ph}=$ Phytane; $\mathrm{TT}=$ tricyclic terpane; $\mathrm{C}_{24} \mathrm{TeT}=\mathrm{C}_{24}$ tetracyclic terpane; $\mathrm{X}=\mathrm{C}_{21}$ tricyclic terpanes; $\mathrm{Y}_{1}=\mathrm{C}_{25}$ tricyclic terpanes; $\mathrm{Z}=\mathrm{C}_{24}$-des-A-ursane; $\mathrm{Z}_{1}=\mathrm{C}_{27}$ tetracyclic terpane. 


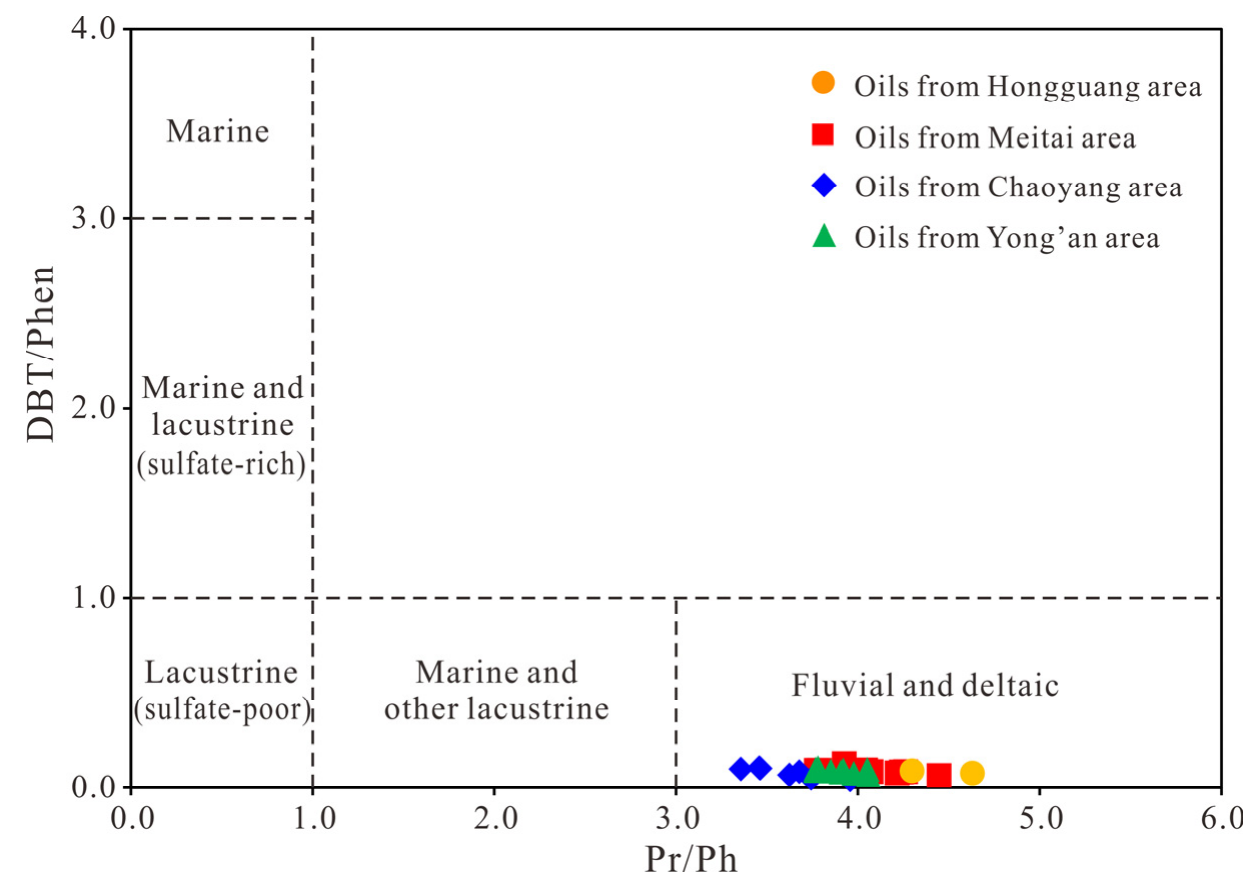

Figure 4. A cross-plot of dibenzothiophene/phenanthrene (DBT/Phen) vs. pristane/phytane (Pr/Ph) ratios for oils from Huangtong Sag (After Hughes et al., 1995 [26]).

\subsubsection{The Distribution of Tricyclic Terpanes}

Tricyclic terpanes (TTs) can often be detected in crude oils and rock extracts. The $13 \beta(\mathrm{H}), 14 \alpha(\mathrm{H})$-TTs, known as regular tricyclic terpanes, can be applied in determining depositional environment, organic matter inputs, and oil group identification [27-29]. Generally, $\mathrm{C}_{23}$ regular tricyclic terpanes are more abundant in crude oils from normal marine and saline lacustrine sources [30,31], while freshwater lacustrine source rocks are characterized by a predominance of $C_{21}$ TT [32]. The distributions of $C_{19}$ and $C_{20}$ TTs may be related to higher plant input, and they commonly predominate in source rocks derived from shallow-water deposits with terrigenous organic matter input [33]. A ternary diagram based on the relative contents of $\mathrm{C}_{19}-\mathrm{C}_{23}$ tricyclic terpanes was found to be generally applicable for identifying the depositional environments of the source rocks and related oils [27,34]. Figure 5 shows a remarkable predominance of $C_{19}$ TT and $C_{20}$ TT in the oils from the Yong'an area, with the $C_{19+20} / C_{23}$ TT values ranging from 4.47 to 5.51 , which suggests a high input of terrigenous higher plant material in the source rocks. Oils from the Meitai and Hongguang areas have a similar distribution of TTs, with relatively lower contents of $\mathrm{C}_{19+20} \mathrm{TT}\left(\mathrm{C}_{19+20} / \mathrm{C}_{23} \mathrm{TT}=1.31 \sim 2.51\right)$. The oils from the Chaoyang oilfield have intermediate values of $\mathrm{C}_{19+20} / \mathrm{C}_{23} \mathrm{TT}(2.19 \sim 4.02)$. 


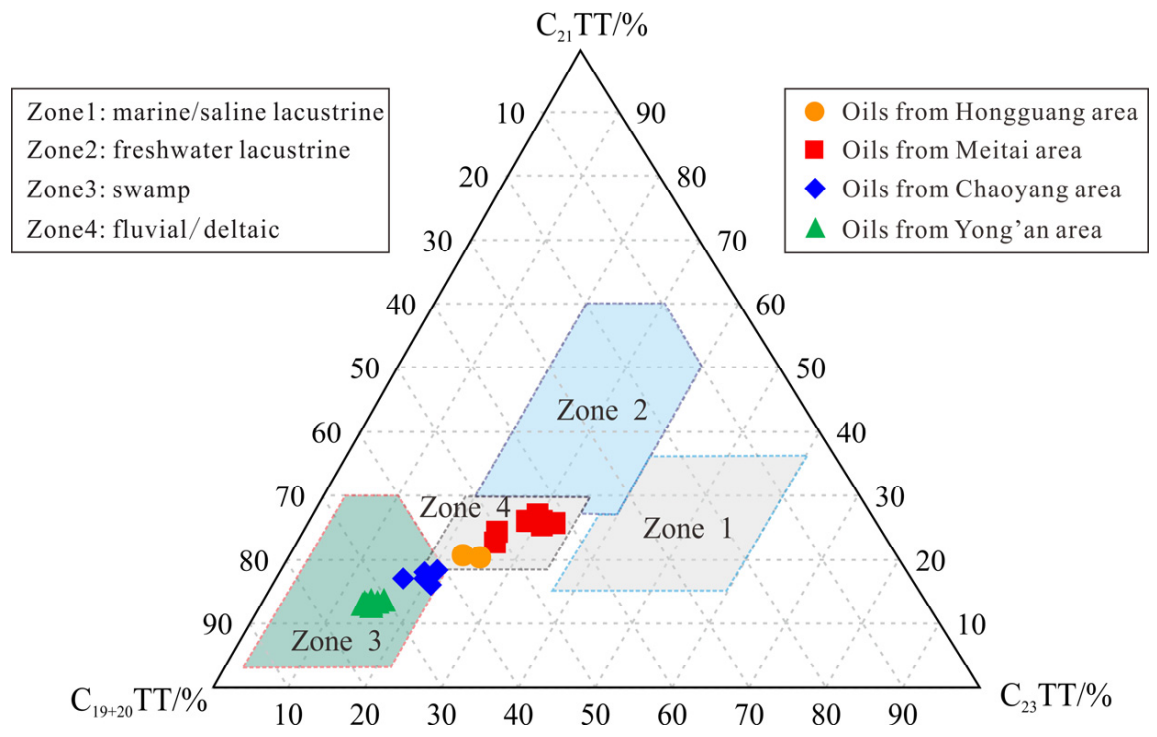

Figure 5. A ternary diagram of $\mathrm{C}_{19+20} \mathrm{TT}, \mathrm{C}_{21} \mathrm{TT}$, and $\mathrm{C}_{23} \mathrm{TT}$ for oils from Huangtong Sag (After Xiao et al., 2019 [27]).

Several unusual tricyclic terpanes and tetracyclic terpanes (designated as compounds $X, Y_{1}, Z$, and $Z_{1}$ ) were also detected in the samples (Figure 3). According to their elution order, relative retention times, and diagnostic ion fragments, compounds $X$ and $Y_{1}$ were determined to be $C_{21}$ and $C_{25}$ tricyclic terpanes, and compounds $Z$ and $Z_{1}$ to be $C_{24}$-des-Aursane and $C_{27}$ tetracyclic terpane [35-38]. These four compounds have analogous chemical structures to oleanane, lupane, and ursane, which are considered to be derived from alcohols or ketone precursors that occur in higher plants [38]. An oxidizing environment may be more favorable for the formation of these unusual compounds [38]. Figure 6 shows the relative contents of these four unusual terpanes. They are more plentiful in oils from the Yong'an and Chao Yang areas, indicating input from higher plants and an oxidizing environment during the formation of their related source rocks. Oils from the Meitai and Hongguang oilfields show similar geochemical characteristics, but with lower contents of these unusual TTs.
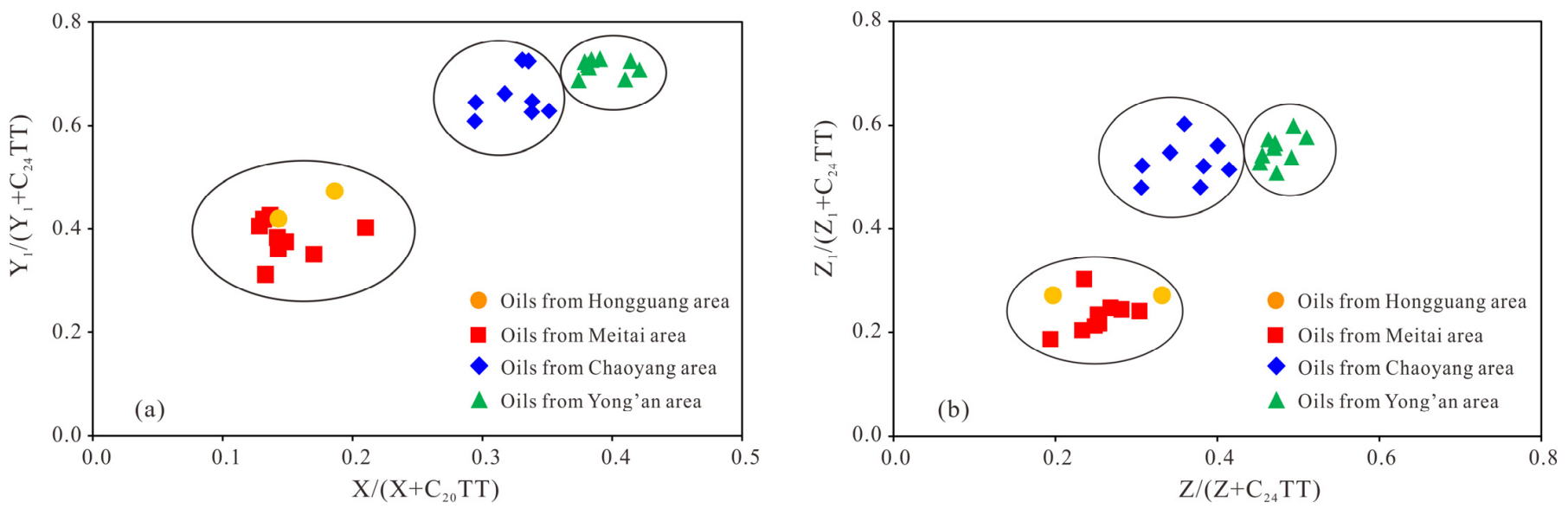

Figure 6. (a) A cross-plot of $\mathrm{Y}_{1} /\left(\mathrm{Y}_{1}+\mathrm{C}_{24} \mathrm{TT}\right)$ vs. $\mathrm{X} /\left(\mathrm{X}+\mathrm{C}_{20} \mathrm{TT}\right)$ for oils from Huangtong Sag. (b) A cross-plot of $Z_{1} /\left(Z_{1}+C_{24} T T\right)$ vs. $Z /\left(Z+C_{24} T T\right)$ for oils from Huangtong Sag. Note: $X=C_{21}$ tricyclic terpanes; $Y_{1}=C_{25}$ tricyclic terpanes; $Z=C_{24}$-des-A-ursane; $Z_{1}=C_{27}$ tetracyclic terpane.

\subsubsection{The Distribution of $C_{27}-C_{30}$ Steranes}

The distributions of $C_{27}-C_{29}$ regular steranes and $C_{30} 4 \alpha$-methyl-24-ethylcholestanes in oils are suggestive of the compositions of organic matter in their related source rocks. All 
the crude oils showed similar $\mathrm{C}_{27}-\mathrm{C}_{28}-\mathrm{C}_{29}$ regular steranes distribution patterns (Figure 7), presenting a " $V$ " shape with a relatively low abundance of $C_{28}$ regular sterane, which may indicate input from both aquatic organisms and terrigenous higher plants.
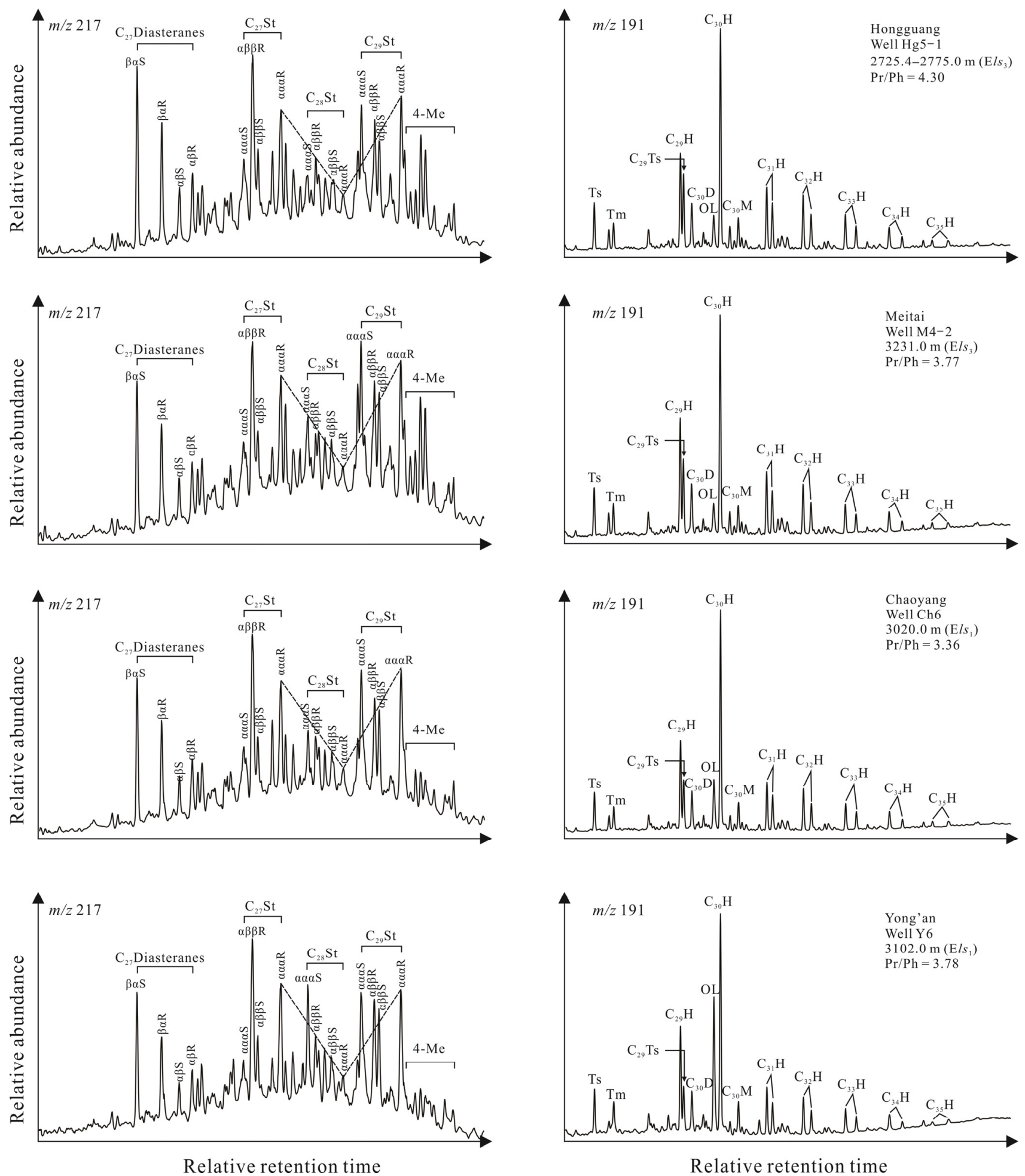

Figure 7. Mass chromatograms $(m / z 217$ and $m / z$ 191) showing the distribution of steranes and hopane series of representative oil samples. Note: $\mathrm{C}_{30} \mathrm{H}-\mathrm{C}_{34} \mathrm{H}=\mathrm{C}_{30}$ hopane- $\mathrm{C}_{34}$ hopane; $\mathrm{Ts}=18 \alpha-$ 22,29,30-trisnorneohopane; $\mathrm{Tm}=17 \alpha-22,29,30$-trisnorhopane; $\mathrm{C}_{29} \mathrm{Ts}=18 \alpha$-30-norneohopane; $\mathrm{C}_{30} \mathrm{D}=$ $\mathrm{C}_{30}$-diahopane; $\mathrm{OL}=$ oleanane. 
$\mathrm{C}_{30} 4 \alpha$-methyl-24-ethylcholestanes generally originate from dinoflagellates in a freshwater lacustrine environment [39]. The $C_{30} 4 \alpha$-methyl-24-ethylcholestanes $/ C_{29}$ sterane values of the oils from the Meitai and Hongguang area (0.42 0.57) are higher than those from the Chaoyang (0.28 0.36) and Yong'an (0.23 0.32) areas, reflecting differences in organic matter input.

\subsubsection{The Distribution of Oleananes}

Oleanane (OL) was first identified in the Niger Delta oils and is considered to derive from angiosperms [40,41]. It is generally abundant in terrestrial plant-derived source rocks and their related oils. The oleanane index (oleanane $/ \mathrm{C}_{30} 17 \alpha(\mathrm{H}), 21 \beta(\mathrm{H})$-hopane) has consistently been applied to determine the contribution of terrestrial higher plants [42]. Abundant oleanane has been detected in the source rocks in the Fushan Depression. The oleanane index is a good indicator for pinpointing the top of the oil generation window and determining oil-source correlation [43]. The Yong'an oils have a relatively high oleanane index, ranging from 0.46 to 0.70 (average 0.58), distinguishing them from Meitai and Hongguang oils, which have a lower oleanane index (average 0.19). Figure 8 shows the significant differences in the relative contents of oleanane $\left(\mathrm{OL} / \mathrm{C}_{30} \mathrm{H}\right)$ and $\mathrm{C}_{30} 4 \alpha$-methyl24-ethylcholestanes (4-Me/ $\mathrm{C}_{29} \mathrm{St}$ ) between oils from the different oilfields. The Hongguang and Meitai oils have higher $4-\mathrm{Me} / \mathrm{C}_{29} \mathrm{St}$ ratios and lower OL/ $\mathrm{C}_{30} \mathrm{H}$ ratios. In contrast, the Yong'an oils have lower $4-\mathrm{Me} / \mathrm{C}_{29} \mathrm{St}$ values and higher OL/ $\mathrm{C}_{30} \mathrm{H}$ values. The widespread occurrence of oleanane and $C_{30} 4 \alpha$-methyl-24-ethylcholestanes in the oil samples reflects significant contributions of terrestrial higher plant organic matter and lacustrine algae. Overall, the relative abundances of oleanane and $C_{30} 4 \alpha$-methyl-24-ethylcholestanes imply different bio-precursor assemblages in the source inputs for these oil fields.

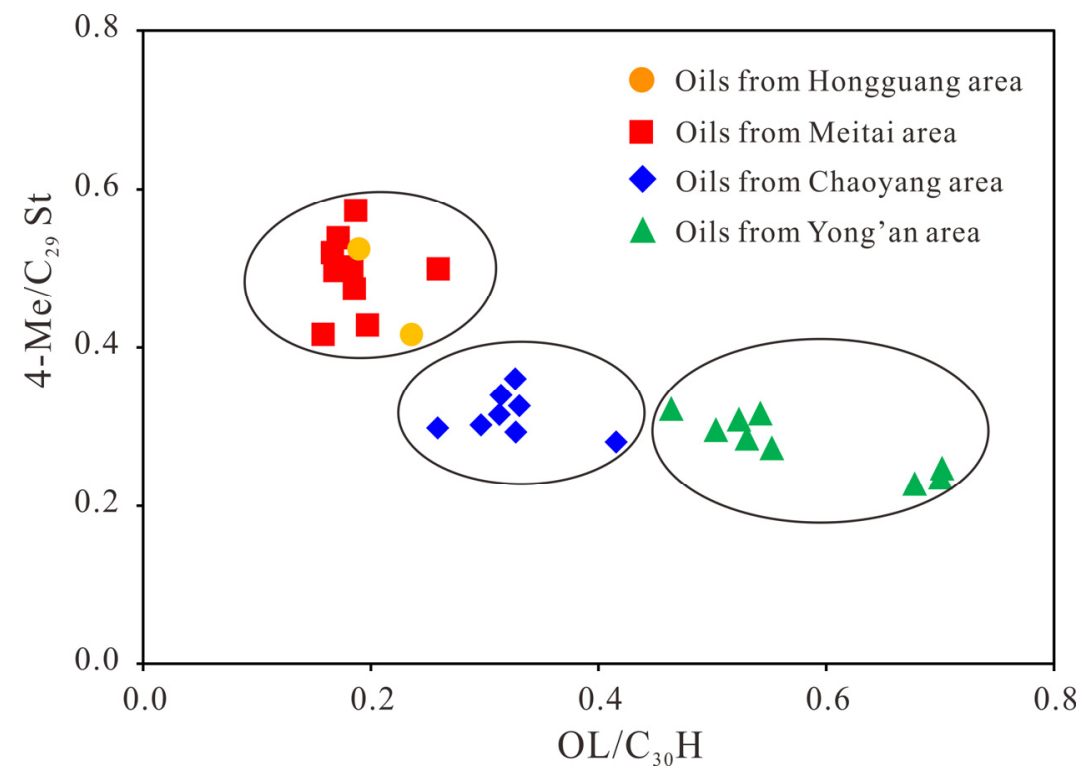

Figure 8. A cross-plot of $4-\mathrm{Me} / \mathrm{C}_{29}$ sterane $\left(4-\mathrm{Me} / \mathrm{C}_{29} \mathrm{St}\right)$ vs. oleanane $/ \mathrm{C}_{30}$ hopane $\left(\mathrm{OL} / \mathrm{C}_{30} \mathrm{H}\right)$ showing the oil family classification in the Huangtong Sag.

The values obtained for several geochemical parameters related to biomarkers provide further confirmation that the source rocks for the different oils formed under similar deposition conditions, in an oxidized freshwater environment, but that their organic matter sources were slightly different.

\subsection{Oil Filling and Entrapment Timing}

\subsubsection{Petrological Observation and Fluid Inclusion Characteristics}

Observations and statistics of thin-sections indicated that the sandstone samples selected from the three sampled wells, M12A, Ch6, and Y11, were mainly medium-coarse 
sandstone. Quartz is dominant among the detrital components, in which micro-cracks and overgrowths are visible. In addition, the Els reservoirs are rich in rock fragments, mostly mudstone fragments. Compared with quartz and lithic fragments, it has a lower abundance of feldspar, with frequent kaolinization and sericitization. The sandstone samples are generally moderately to poorly sorted, with subrounded to subangular grains. The linear to concavo-convex grain contacts of mineral particles shows that the reservoirs have experienced strong mechanical compaction.

Fluid inclusions can be used to determine the hydrocarbon accumulation period [44]. The fluid inclusions examined in this study are mainly found in quartz overgrowth and in micro-fissures through quartz particles (Figure 9), presenting rectangular, elliptical, or irregular shapes, and generally with a striped distribution. The hydrocarbon inclusions can be identified by UV-epifluorescence, with the majority showing light yellow fluorescence and the minority light blue. Both the aqueous inclusions and the petroleum inclusions used for temperature determination are two-phase at room temperature.

\subsubsection{Microthermometry of fluid inclusions}

The vapor-liquid ratios of the aqueous and petroleum fluid inclusions in the sandstone samples are usually less than $10 \%$ at room temperature $\left(24^{\circ} \mathrm{C}\right)$, indicating that they are homogeneous at high temperatures [45]. Microthermometric analysis was performed on the two-phase inclusions, including both the oil inclusions and their paragenetic brine inclusions. The homogeneity temperatures (Th) and the ice-melting temperatures (Tm, ice) were measured, in which Th can be used to determine the timing of hydrocarbon accumulation, and Tm can characterize the salinity of water during the formation of brine inclusions [46].

Microthermometry of fluid inclusions in the sandstone samples from the wells shows only one period of fluid inclusion formation. A total of 137 Th data points were acquired, and histograms of the Th values of the three wells exhibited a consistent unimodal distribution pattern (Figure 10).

The peak homogenization temperatures of fluid inclusions in the wells are $85-110{ }^{\circ} \mathrm{C}$ (M12A), $100-110{ }^{\circ} \mathrm{C}$ (Ch6), and $110-120{ }^{\circ} \mathrm{C}$ (Y11). Salinities of the brine inclusions in wells M12A and Ch6 mostly range from 8 to 10 percent by weight (wt.\%) (NaCl. eqv.). The salinity values from Tm in well Y11 are between 6 and 8 percent by weight (wt.\%) ( $\mathrm{NaCl}$. eqv). The homogeneity temperature and salinity results suggest that at least one oil-charging event occurred in the Els reservoirs of the Meitai, Chaoyang, and Yong'an oilfields.

\subsubsection{Timing and Episodes of Oil Charging}

Trapping temperatures can be correlated with the relative geological ages of hydrocarbon charging and entrapment events by 1D numerical simulation of burial and geothermal histories. The depositional burial and thermal histories of wells M12A, Ch6, and Y11 were reconstructed using Basinmod-1D software.

Beibuwan Basin is an extensional basin located on the northern continental shelf of the South China Sea (SCS). The geothermal gradient and heat flow values of the northern marginal basins of the SCS are higher than those basins in central and western China, such as Ordos basin, Sichuan Basin and Tarim Basin. The northern marginal basins of the SCS are typical "hot basins" with average heat flow values $72.6 \pm 15.6 \mathrm{~mW} / \mathrm{m}^{2}$ [47] The distribution of present geothermal flow is different in the northern continental shelf of the SCS. The Beibuwan Basin has a relatively low heat flow with an average of 61.20 $\mathrm{mW} / \mathrm{m}^{2}$ among these basins [48]. Kang et al. (1995) indicated that the current average heat flow of the Beibuwan Basin is $61.71 \mathrm{~mW} / \mathrm{m}^{2}$ and the average geothermal gradient is $3.72{ }^{\circ} \mathrm{C} / \mathrm{hm}$ [49]. The thermal history of Bailian Sag was reconstructed using 1-D basin modeling. The results suggested maximum value of hydrothermal flow in the rifting stage of the Early Eocene reached $68.6 \mathrm{~mW} / \mathrm{m}^{2}$, and then deduced gradually by the end of the Late Miocene. From the Early Pliocene, the value started to rise again [7]. Due to the diverse 
tectonic thermal events in the east and west of the Fushan Depression, the paleo-heat flow evolution of Bailian Sag may be different from the Huangtong Sag $[8,19]$.
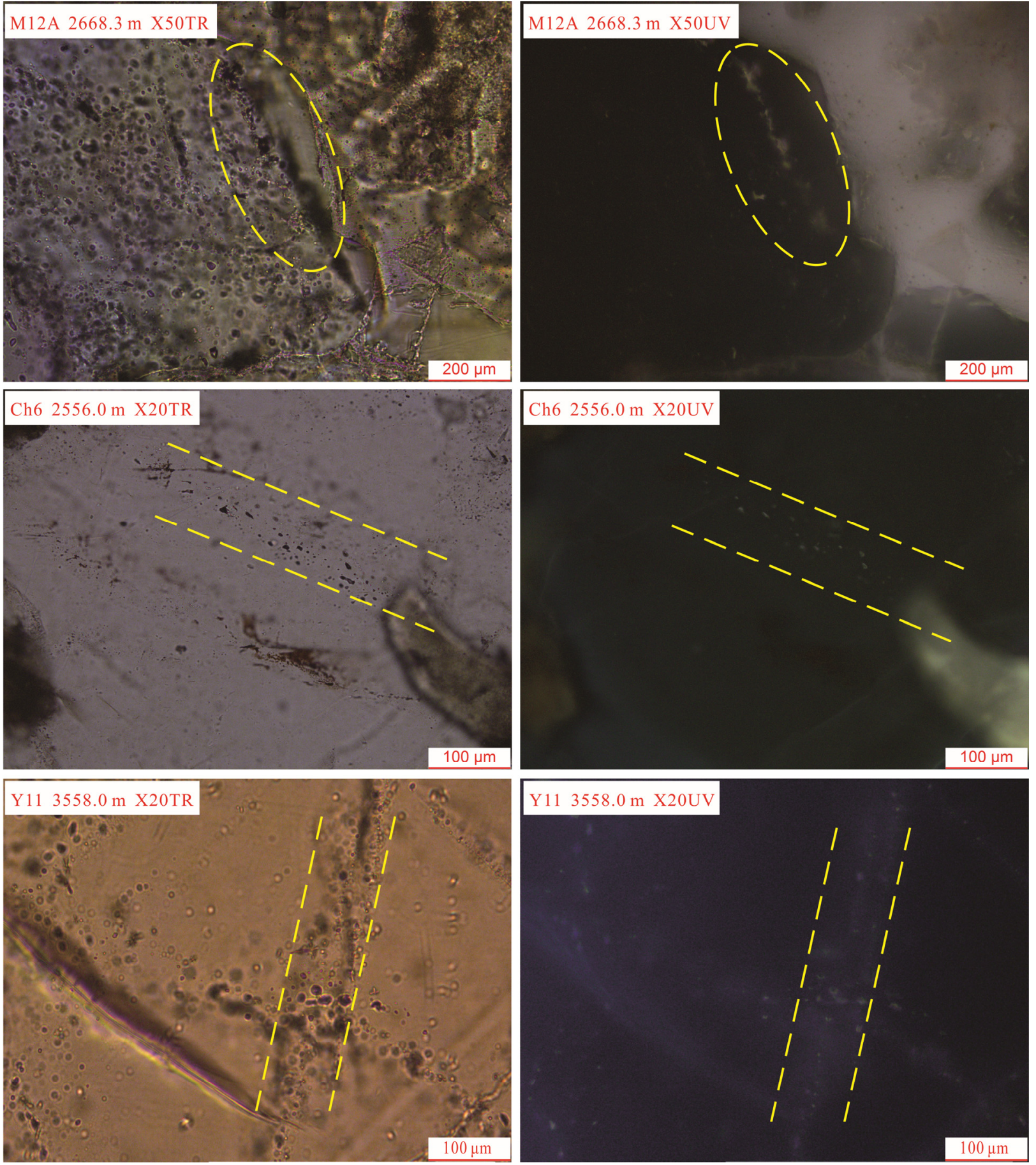

Figure 9. Characteristics of typical fluid inclusions under transmitted light (TR) and ultraviolet light (UV) observed at room temperature. 

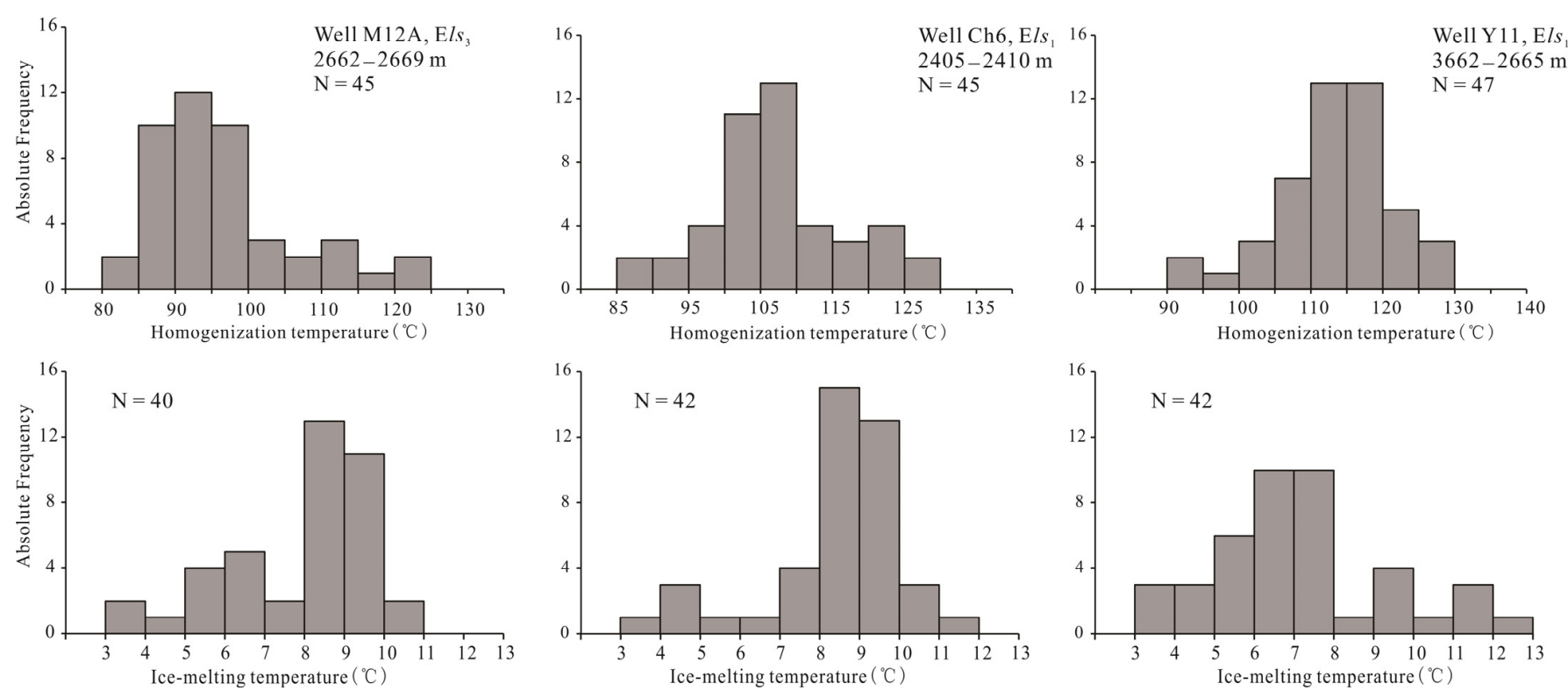

Figure 10. The histograms of the homogenization temperature (Th) and the ice-melting temperatures (Tm).

Paleo-heat flow evolution models of the Meitai, Chaoyang, and Yong'an fields were simulated based on the reconstruction of their burial histories. Measured vitrinite reflectance values (\%Ro) were used to calibrate the models. The three models were similar, with all the thermal histories characterized by an inflection point at about $10 \mathrm{Ma}$. During the late Paleocene to the early Eocene (50 Ma), due to the collision between the Indosinian and Eurasian plates, the Beibuwan basin was pulled apart and experienced a fault depression event $[7,49]$. Deep faults communicated with the magmatic heat source at the bottom in the early Eocene, inducing higher heat flow. The geothermal gradient and the paleo-heat flow then began to decrease as the evolution of the stress field caused a change from rifting to sagging [7]. Since the early Pliocene (10 Ma), heat flow has increased rapidly, perhaps under the influence of thermal events (magmatic activity, etc.). The current heat flow in the three areas is approximately $55-57 \mathrm{~mW} / \mathrm{m}^{2}$.

Figure 11 shows the burial-thermal history and Ro profile correction for well Y11. Combining this with the homogenization temperatures of hydrocarbon inclusions, the charging times of oils in the Meitai, Chaoyang, and Yong'an fields can be determined. Although the Th values of the fluid inclusions in the three wells are different, their corresponding accumulation times are almost the same. The results suggest that the geological timings of oil charging are between the late Miocene and the early Pliocene, and that the corresponding accumulation times in the Meitai, Chaoyang, and Yong'an fields are 2-8 Ma, 2-7 Ma, and 3-6 Ma, respectively. This correlates to the Dongsha Movement, which played a pivotal role in hydrocarbon accumulation in the Fushan Depression [50].

\subsection{Oil Charging Orientation and Reservoir Filling Pathways in the Huangtong Sag}

England et al. (1987) proposed an oil charging model for sandstone reservoirs that provides a theoretical foundation for the reconstruction of oil charging directions and filling pathways. Determination of petroleum migration directions is vital for predicting potential source kitchens and commercial "satellite accumulations" [51]. Based on the migration fractionation effects and thermal maturity of crude oils, a set of geochemical parameters has been established for tracing hydrocarbon migration directions [52-54]. 

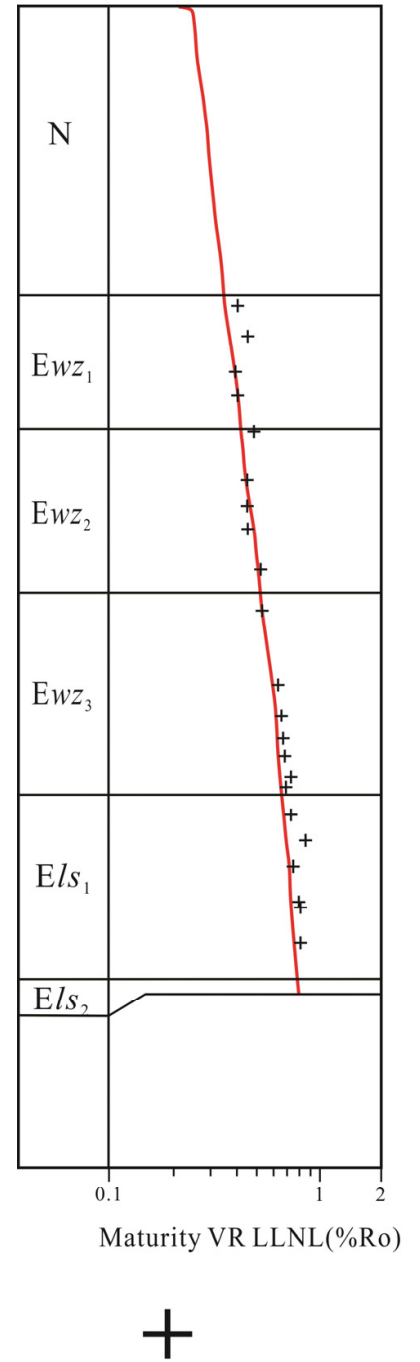

Measured \%Ro
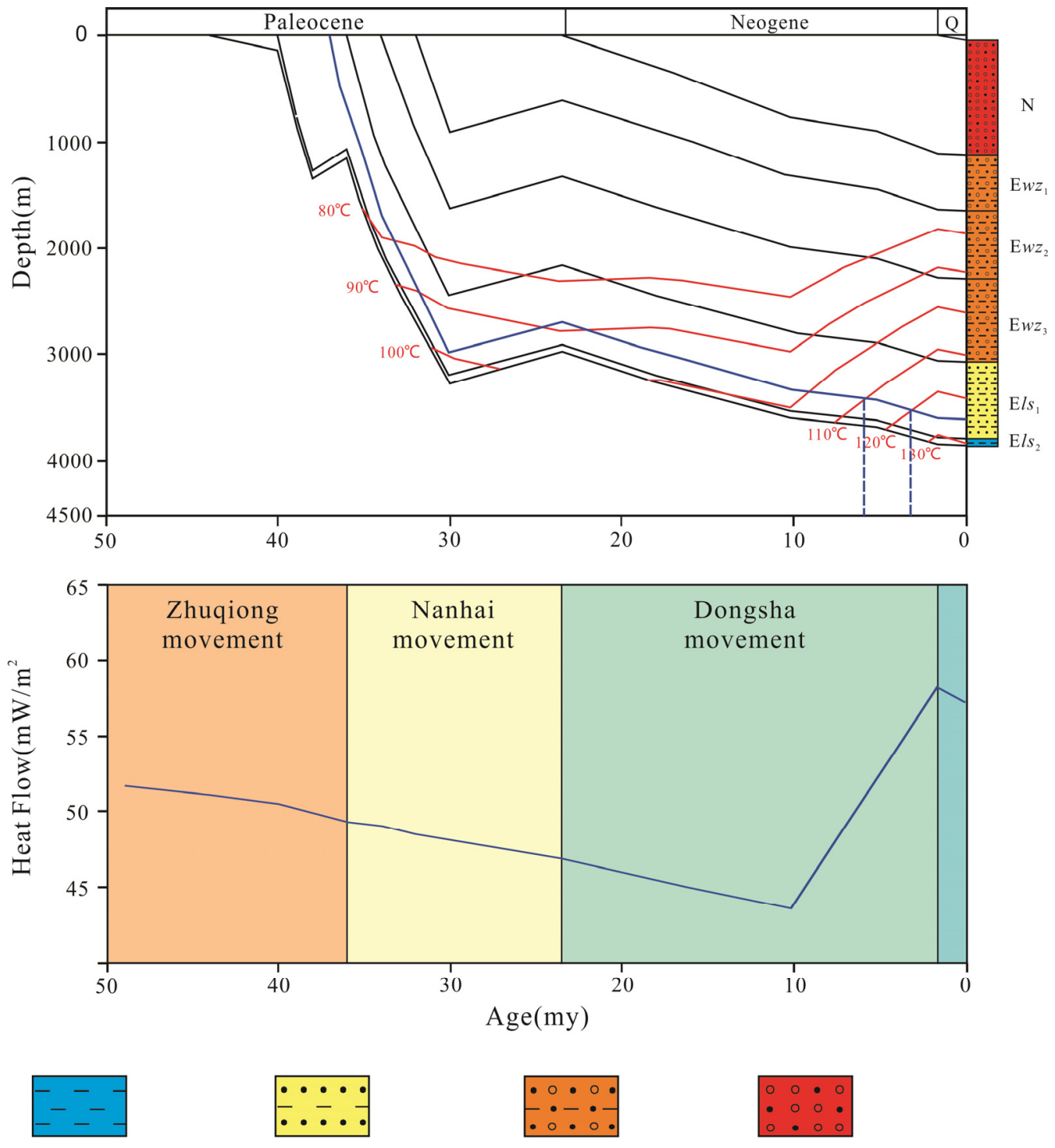

Fan delta and

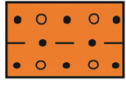

Fluvial facies

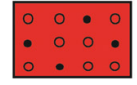

Alluvial fan

$$
\text { braided river delta }
$$

Figure 11. Reconstructed paleo-heat flow model, stratigraphic, burial, and thermal history of the Well Y11.

Dibenzothiophene (DBT), dibenzofuran (DBF), and their methylated homologs are important heterocyclic aromatic compounds in sedimentary organic matter and crude oils. In previous studies, alkyl DBTs have mainly been applied in the maturity assessment of oils and source rocks [55-59] and the depositional environment of source rocks [26,60]. Based on their thermodynamic stability and hydrogen bonding mechanisms, 4-/1-MDBT, 2,4-/1,4and 4,6-/1,4-DMDBT are used as tracer parameters for hydrocarbon migration in sandstone and carbonate reservoirs [61]. DBF-related parameters, such as the 1-/4-MDBF ratio, have also been used to trace petroleum migration orientations and filling pathways in sandstone reservoirs according to molecular simulation and quantum chemistry calculations [16,62]. The geo-chromatographic fractionation effect of these two MDBF isomers is also apparent on dolomite surfaces, so the 1-/4-MDBF ratio can also be applied to trace oil migration in dolomite reservoirs [63].

A number of geochemical parameters, related to alkyl dibenzothiophenes, alkyl dibenzofurans, benzo[b] naphthothiophenes, alkyl naphthalenes, phenanthrenes, etc., have been used to trace the oil filling pathways of the Huachang Uplift [9-16]. In this study, dibenzothiophene (DBT), dibenzofuran (DBF), and their methylated homologs were identified in 
all the oils from the Huangtong Sag. Thus, the two molecular geochemical parametersthe 4-/1-MDBT and 1-/4-MDBF ratios-were selected for direction and pathway tracing. Based on the biomarker composition of the crude oils, three oil groups were identified in the Huangtong Sag. The similarities in geochemical compositions between the oils from the Meitai and Hongguang oilfields suggest that they belong to the same oil family and distinguish them from oils from the Chaoyang and Yong'an oilfields. The hydrocarbon migration and filling pathways in the Hongguang-Meitai area are therefore discussed separately from those in the Chaoyang and Yong'an areas.

Figures 12 and 13 show the oil migration orientations and filling pathways indicated by an isopleth map of the 4-/1-MDBT and 1-/4-MDBF ratios. The decreasing direction of the ratios indicates the oil migration orientation. Although the isopleth distribution based on 4-/1-MDBT does not coincide exactly with that of 1-/4-MDBF, the hydrocarbon migration and charging directions are roughly consistent. Crude oils in the Yong'an area migrate from northwest to southeast, indicating that the source rocks for these oils are located in the northwest of the Yong'an area.

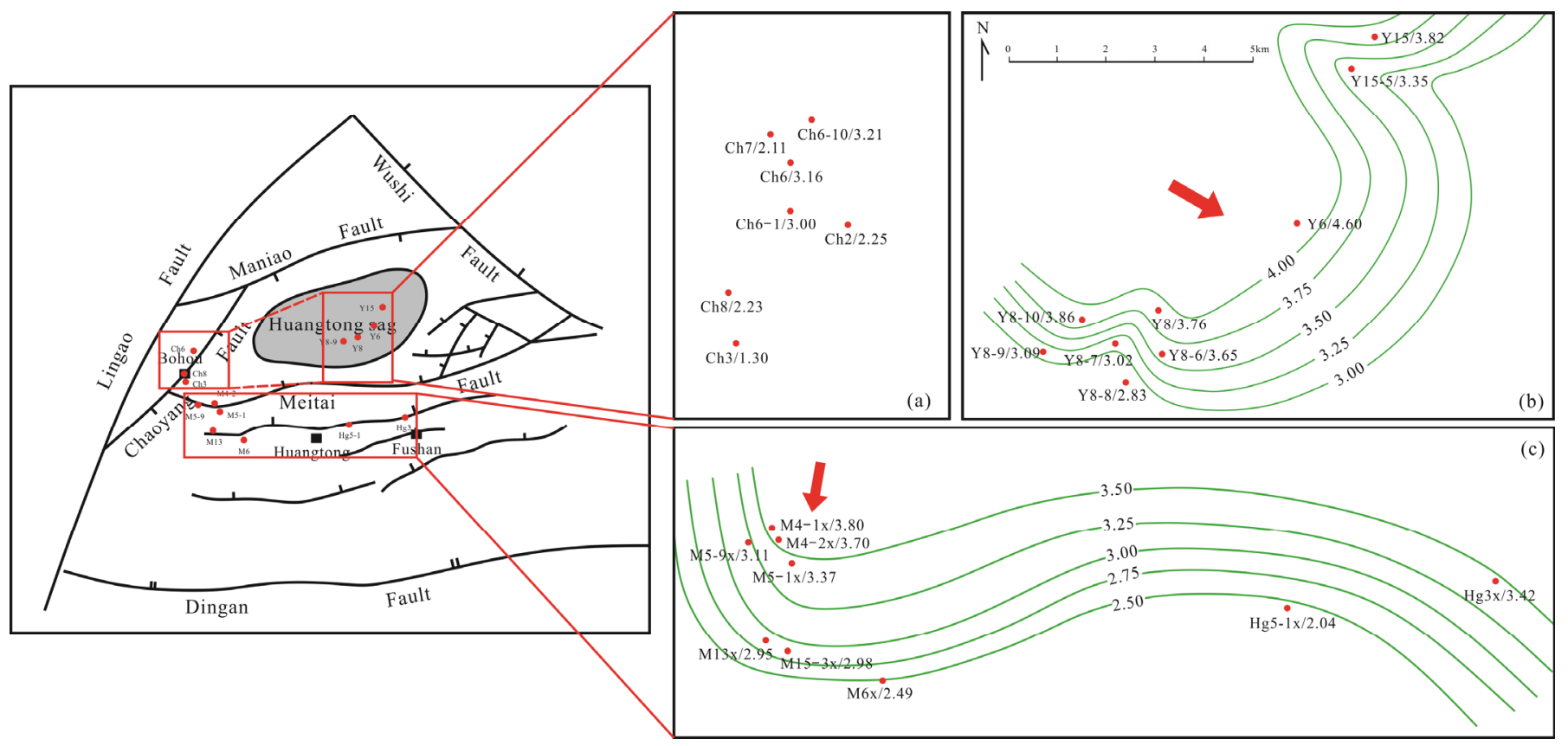

Figure 12. Isopleth map of 4-/1-MDBT of oils showing the oil migration orientation and charging pathways in the Chaoyang area (a), Yong'an area (b) and Hongguang-Meitai area (c). Note: MDBT, methyldibenzothiophene.

The Hongguang and Meitai oilfields are located in the southern slope area, mainly developed the braided river delta in $\mathrm{E} l_{3}[4,5,23]$. The braided river delta front sand-body and associated faults are important carrier beds for migration of the Hongguang-Meitai oils, as the crude oil from $\mathrm{E} l_{3}$ migrates from north to south along the sandstone of the fan delta front (Figures 12 and 13). In the Chaoyang area, the data points have no obvious decreasing direction on the plane. Vertically, however, crude oils in the shallower reservoirs have lower 4-/1-MDBT and 1-/4-MDBF values (Table 1). The Chaoyang oilfields are situated in the northern fault step belt and the widely developed consequent fault may be the principal petroleum migration pathway for accumulations in the Chaoyang oil fields (Figure 14) [64]. 


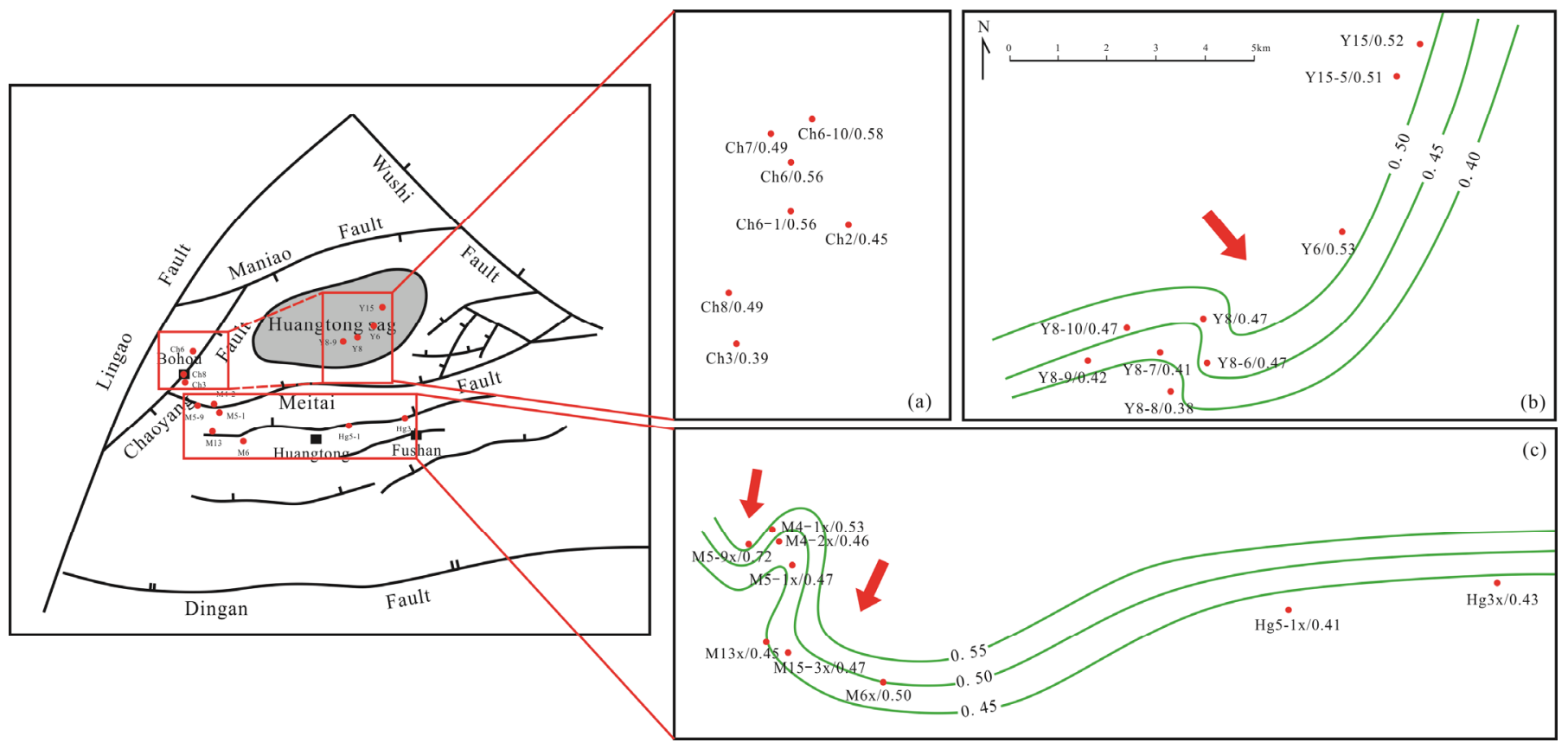

Figure 13. Isopleth map of 1-/4-MDBF of oils showing the oil migration orientation and charging pathways in the Chaoyang area (a), Yong'an area (b), and Hongguang-Meitai area (c). Note: MDBF, methyldibenzofuran.

Table 1. 4-/1-MDBT and 1-/4-MDBF data of the oil samples from the Huangtong Sag.

\begin{tabular}{|c|c|c|c|c|c|}
\hline Sample & Well & $\operatorname{Depth}(\mathrm{m})$ & $\begin{array}{l}\text { Sequence } \\
\text { Name }\end{array}$ & 4-/1-MDBT & 1-/4-MDBF \\
\hline No.1 & Y8-8 & 2773 & $\mathrm{E} l s_{1}$ & 2.83 & 0.38 \\
\hline No. 2 & Y8 & 2860 & $\mathrm{E} l_{s_{1}}$ & 3.76 & 0.47 \\
\hline No.3 & Y8-9 & 2973 & $\mathrm{E} l s_{1}$ & 3.09 & 0.42 \\
\hline No.4 & Y8-6 & 3000 & $\mathrm{E} l s_{1}$ & 3.65 & 0.47 \\
\hline No.5 & Y15 & 3026 & $\mathrm{E} l s_{1}$ & 3.82 & 0.52 \\
\hline No.6 & Y8-7 & 3042 & $\mathrm{E} l s_{1}$ & 3.02 & 0.41 \\
\hline No.7 & Y8-10 & 3101 & $\mathrm{E} l s_{1}$ & 3.86 & 0.47 \\
\hline No.8 & $\mathrm{Y} 6$ & 3102 & $\mathrm{E} l s_{1}$ & 4.60 & 0.53 \\
\hline No.9 & Y15-5 & 3102 & $\mathrm{E} l s_{1}$ & 3.35 & 0.51 \\
\hline No.10 & $\mathrm{Hg} 3$ & 2508 & $\mathrm{Els}_{3}$ & 3.42 & 0.43 \\
\hline No.11 & Hg5-1 & 2750 & $\mathrm{Els}_{3}$ & 2.04 & 0.41 \\
\hline No.12 & M4-1 & 3340 & $\mathrm{E} l s_{3}$ & 3.04 & 0.53 \\
\hline No.13 & M4-1 & 3476 & $\mathrm{E} l s_{3}$ & 3.80 & 0.73 \\
\hline No.14 & M4-2 & 3231 & $\mathrm{E} l s_{3}$ & 3.70 & 0.46 \\
\hline No.15 & M5-1 & 3150 & $\mathrm{E} l_{s_{3}}$ & 3.36 & 0.47 \\
\hline No.16 & M5-1 & 3155 & $\mathrm{E} l s_{3}$ & 3.37 & 0.47 \\
\hline No.17 & M5-9 & 3437 & $\mathrm{Els}_{3}$ & 3.11 & 0.72 \\
\hline No.18 & M6 & 2629 & $\mathrm{E} l s_{3}$ & 2.49 & 0.50 \\
\hline No.19 & M13 & 2838 & $\mathrm{Els}_{3}$ & 2.95 & 0.45 \\
\hline No.20 & M15-3 & 3131 & $\mathrm{E} l s_{3}$ & 2.98 & 0.47 \\
\hline No.21 & Ch7 & 2417 & $\mathrm{E} l_{s}$ & 2.11 & 0.49 \\
\hline No.22 & Ch2 & 2504 & $\mathrm{E} l s_{1}$ & 2.25 & 0.45 \\
\hline No.23 & Ch8 & 2779 & $\mathrm{E} l s_{1}$ & 2.23 & 0.49 \\
\hline No.24 & Ch3 & 2836 & $\mathrm{E} l s_{1}$ & 2.30 & 0.50 \\
\hline No.25 & Ch6 & 3020 & $\mathrm{E} l s_{1}$ & 3.16 & 0.56 \\
\hline No.26 & Ch6-1 & 3321 & $\mathrm{E} l s_{1}$ & 3.00 & 0.56 \\
\hline No.27 & Ch6-10 & 4070 & $\mathrm{E} l s_{2}$ & 3.21 & 0.58 \\
\hline
\end{tabular}




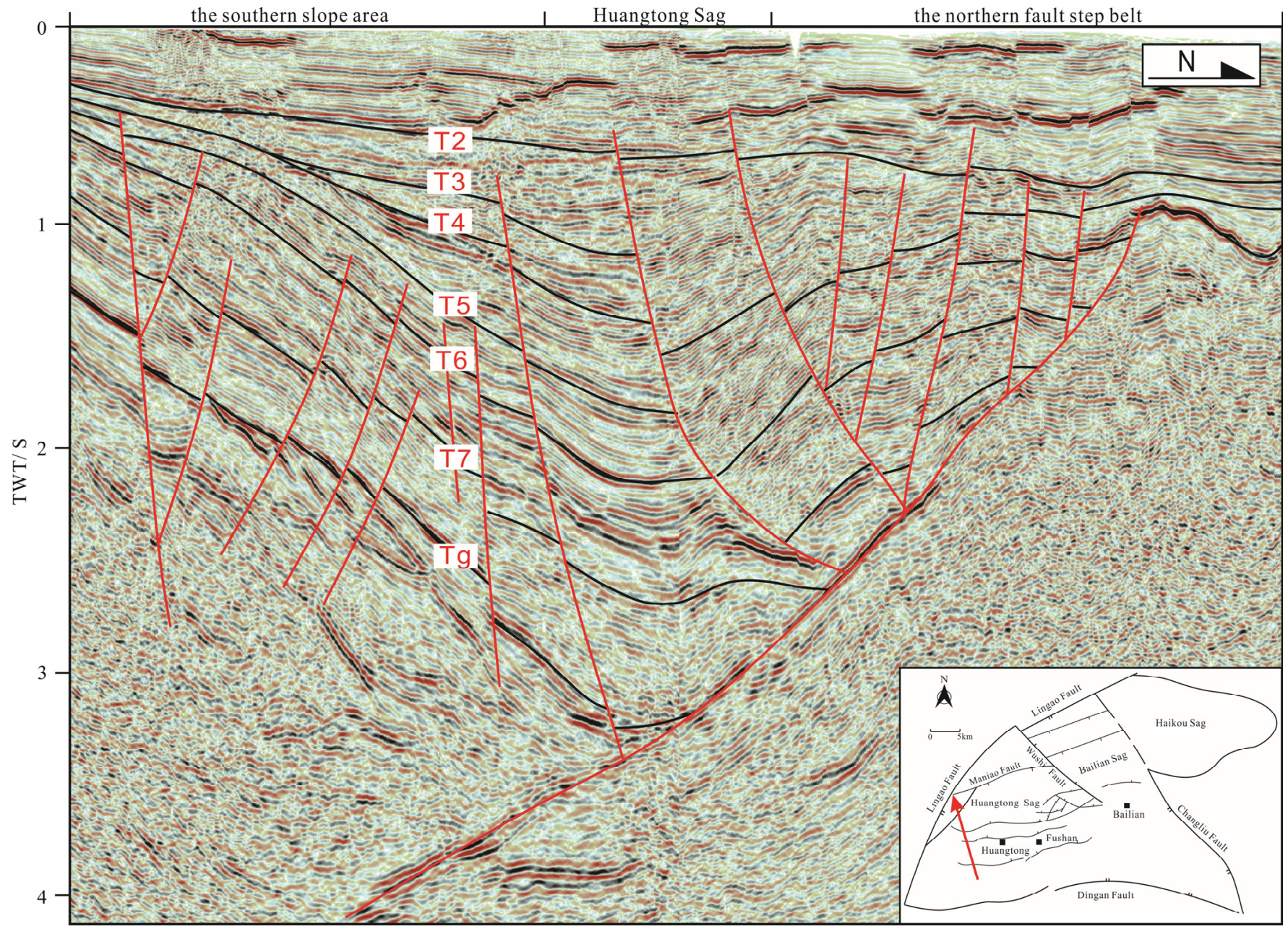

Figure 14. Interpreted seismic section (S-N direction) showing the consequent fault in the Chaoyang area.

\subsection{Implications for Petroleum Exploration}

Tracing the oil charging process shows that the crude oil in Els $s_{1}$ reservoirs in the Yong'an area generally migrates from northwest to southeast, indicating a source kitchen in the north of the Huangtong Sag. Zeng et al. (2022, unpublished) found that the lacustrine depositional center has shifted with time, and that the effective source rock kitchens of $\mathrm{E} l s_{1}$ are located in the northern part of the Huangtong Sag [65]. The northwest part of the Yong'an area is, therefore, the most favorable exploration block.

Oil migration from north to south in the Hongguang-Meitai area indicates that the hydrocarbon source kitchen is located in the northern part, probably in the center of the Huangtong Sag. The predicted locations of the source kitchens in this study are consistent with previous studies [2,3]. In recent years, several boreholes have been drilled in the north part of the Hongguang-Meitai area, and commercial oil flows have been obtained. Therefore, along the oil charging pathway, the northern part of the Hongguang-Meitai area is already proving to be the most prolific for petroleum exploration.

\section{Conclusions}

All of the oils in this study are derived from mixed input source rocks deposited in an oxidizing environment. There are slight differences among the oils. Oils from the Meitai and Hongguang areas have similar geochemical characteristics, with higher $4 \alpha$-methyl24-ethylcholestane contents, and may be derived from the same or similar source rocks with a greater contribution of aquatic organisms. The crude oils in the Yong'an area have 
an abundance of oleanane and $\mathrm{C}_{19 \sim 20}$ tricyclic terpane, and also contain several unusual tricyclic terpanes, which probably originated from source kitchens supplied by mostly terrigenous plant organic matter. The oils from the Chaoyang fall somewhere in between.

Hydrocarbon accumulation in the Paleogene sandstone reservoirs in the Huangtong Sag occurred between the end of the Middle Miocene and the early Pliocene, and there was only one episode of hydrocarbon charging, which is estimated to have been between 8-2 Ma.

The general orientation of oil migration in the Yong'an Oilfield is from northwest to southeast, suggesting that the source kitchen for the oils in the Yong'an area is located in the north of the Huangtong Sag. In the southern slope area (the Hongguang and Meitai oilfields), the crude oil migrates from north to south, laterally along the sand body. The hydrocarbon source kitchen for the Hongguang-Meitai area is therefore likely to be in the north part of the area. The sandstone of the braided river delta front is considered to provide good carrier beds for these oils. In the northern fault step belt (the Chaoyang area), the widely developed faults serve as conduits for oil migration. The lower sand bodies are likely to be the most prolific exploration targets in this area.

Author Contributions: Conceptualization, Z.L., M.L. and X.W.; methodology, X.W., Z.Z. and C.Y.; software, F.W.; validation, Z.L. and M.L.; formal analysis, H.G. and X.L.; investigation, X.W., Z.Z. and B.Z.; resources, H.G.; data curation, Z.R.; writing-original draft preparation, X.W.; writingreview and editing, M.L.; visualization, X.W.; supervision, M.L.; project administration, Z.L. and H.G.; funding acquisition, Z.L. All authors have read and agreed to the published version of the manuscript.

Funding: This research was funded by the South Oil Exploration and Development Company of PetroChina, grant number 2020-HNYJ-003.

Institutional Review Board Statement: Not applicable.

Informed Consent Statement: Not applicable.

Data Availability Statement: Not applicable.

Acknowledgments: This research was financially supported by the South Oil Exploration and Development Company of PetroChina (2020-HNYJ-003). We would also like to thank Shi Shengbao, Zhu Lei and Zhang Jianfeng of China University of Petroleum (Beijing) for their assistance and guidance during the experiment. The authors would like to thank three anonymous reviewers and editors for their constructive suggestions and comments which significantly improve the quality of this manuscript.

Conflicts of Interest: The authors declare no conflict of interest.

\section{References}

1. Gan, H.J.; Wang, H.; Shi, Y.; Ma, Q.L.; Liu, E.T.; Yan, D.T.; Pan, Z.J. Geochemical characteristics and genetic origin of crude oil in the Fushan sag, Beibuwan Basin, South China Sea. Mar. Pet. Geol. 2020, 112, 104114. [CrossRef]

2. Li, M.J.; Wang, T.G.; Liu, J.; Zhang, M.Z.; Lu, H.; Ma, Q.L.; Gao, L.H. Characteristics of oil and gas accumulation in Yong'an-Meitai area of the Fushan Depression, Beibuwan Basin, South China Sea. Pet. Sci. 2007, 4, 23-33.

3. Lu, Z.H.; Gan, H.J.; Shi, Y.; Chen, S.B.; Wang, H.; Ma, Q.L. Geochemical Characteristics of crude oil and oil-source correlation in the western Fushan Depression. Earth Sci. 2016, 41, 1909-1920. (In Chinese)

4. Liu, E.T.; Wang, H.; Li, Y.; Zhou, W.; Leonard, N.D.; Lin, Z.L.; Ma, Q.L. Sedimentary characteristics and tectonic setting of sublacustrine fans in a half-graben rift depression, Beibuwan Basin, South China Sea. Mar. Pet. Geol. 2014, 52, 9-21. [CrossRef]

5. Liu, E.T.; Wang, H.; Li, Y.; Leonard, N.D.; Feng, Y.X.; Pan, S.Q.; Xia, C.Y. Relative role of accommodation zones in controlling stratal architectural variability and facies distribution: Insights from the Fushan Depression, South China Sea. Mar. Pet. Geol. 2015, 68, 219-239. [CrossRef]

6. Wang, G.H.; Wang, H.; Gan, H.J.; Shi, Y.; Zhao, Y.D.; Chen, S.B. Oil source and migration process in oblique transfer zone of Fushan Sag, northern South China Sea. J. Cent. South Univ. 2016, 23, 654-668. [CrossRef]

7. Chen, S.B.; Gan, H.J.; Xia, C.Y.; Zhao, Y.D.; Wang, G.H.; Wang, X. History Simulation of Thermal Evolution and Hydrocarbon Generation of Source Rocks in Bailian Sub-Sag, Fushan Sag, Beibuwan Basin. Xinjiang Pet. Geol. 2014, 35, 672-677. (In Chinese)

8. Liu, E.T.; Wang, H.; Uysal, I.T.; Zhao, J.X.; Wang, X.C.; Feng, Y.X.; Pan, S.Q. Paleogene igneous intrusion and its effect on thermal maturity of organic-rich mudstones in the Beibuwan Basin, South China Sea. Mar. Pet. Geol. 2017, 86, 733-750. [CrossRef] 
9. Li, M.J.; Wang, T.G.; Liu, J.; Zhang, M.Z.; Lu, H.; Ma, Q.; Gao, L.H. Total alkyl dibenzothiophenes content tracing the filling pathway of condensate reservoir in the Fushan Depression, South China Sea. Sci. China Ser. D-Earth Sci. 2008, 51, $138-145$.

10. Li, M.J.; Wang, T.G.; Liu, J.; Zhang, M.Z.; Lu, H.; Ma, Q.L.; Gao, L.H. Alkyl Naphthalenes and Phenanthrenes: Molecular Markers for Tracing Filling Pathways of Light Oil and Condensate Reservoirs. Acta Geol. Sin.-Engl. Ed. 2010, 84, $1294-1305$.

11. Li, M.J.; Wang, T.G.; Yang, F.L.; Shi, Y. Molecular Tracer Markers for Filling Pathway in Condensate Reservoirs: Alkyldibenzofuran. J. Oil Gas Technol. 2011, 33, 6-11. (In Chinese)

12. Li, M.J.; Wang, T.G.; Shi, S.B.; Liu, K.Y.; Ellis, G.S. Benzonaphthothiophenes and alkyl dibenzothiophenes: Molecular tracers for oil migration distances. Mar. Pet. Geol. 2014, 57, 403-417. [CrossRef]

13. Li, M.J.; Wang, T.G. The progress and application of reservoir geochemistry in hydrocarbon exploration: An example from the Fushan Depression, Beibuwan Basin, South China Sea. Earth Sci. Front. 2015, 22, 215-222. (In Chinese)

14. Yang, L.; Li, M.J.; Wang, T.G.; Shi, Y. Dibenzothiophenes and benzonaphthothiophenes in oils, and their application in identifying oil filling pathways in Eocene lacustrine clastic reservoirs in the Beibuwan Basin, South China Sea. J. Pet. Sci. Eng. 2016, 146, 1026-1036. [CrossRef]

15. Fang, R.H.; Li, M.J.; Wang, T.G.; Liu, X.Q.; Yuan, Y.; Jiang, W.D.; Wang, D.W.; Shi, S.B. Trimethyldibenzothiophenes: Molecular tracers for filling pathways in oil reservoir. J. Pet. Sci. Eng. 2017, 159, 451-460. [CrossRef]

16. Li, M.J.; Liu, X.Q.; Wang, T.G.; Jiang, W.D.; Fang, R.H.; Yang, L.; Tang, Y.J. Fractionation of dibenzofurans during subsurface petroleum migration: Based on molecular dynamics simulation and reservoir geochemistry. Org. Geochem. 2018, 115, 220-232. [CrossRef]

17. Ma, Q.L.; Zhao, S.E.; Liao, Y.T.; Lin, Z.L. Sequence architectures of Paleogene Liushagang Formation and its significance in Fushan Sag of the Beibuwan Basin. J. China Univ. Geosci. (Chin. Ed.) 2012, 37, 667-678. (In Chinese)

18. Wang, G.H.; Huang, C.Y.; Liu, E.T.; Li, Y.; Pan, S.Q. Characteristics of slope-breaks and its control on sedimentation and hydrocarbon accumulation of Liushagang Formation in gentle slope of south Fushan sag. J. Cent. South Univ. 2014, 45, 1531-1542. (In Chinese)

19. Liu, E.T.; Uysal, I.T.; Wang, H.; Feng, Y.X.; Pan, S.Q.; Yan, D.T.; Nguyen, A.D.; Zhao, J.X. Timing and characterization of multiple fluid flow events in the Beibuwan Basin, northern South China Sea: Implications for hydrocarbon maturation. Mar. Pet. Geol. 2021, 123, 104754. [CrossRef]

20. Li, M.J.; Wang, T.G.; Liu, J.; Zhang, M.Z.; Lu, H.; Ma, Q.L.; Gao, L.H. A discussion on hydrocarbon accumulation dating determined by homogenization temperature and burial history of fluid inclusio-An example from the Fushan depression, Beibuwan Basin. Oil Gas Geol. 2007, 28, 151-158. (In Chinese)

21. Cao, H.Y.; Jin, S.D.; Sun, M.; Wang, H. Astronomical forcing of sedimentary cycles of late Eocene Liushagang formation in the Bailian sag, Fushan sag, Beibuwan basin, south China sea. J. Cent. South Univ. 2016, 23, 1427-1438. [CrossRef]

22. Lin, Z.L.; Wang, H.; Li, H.J.; Ma, Q.L.; Li, Y.; Zhao, S.E. Genetic mechanism of double-layer structure in Paleogene of Fushan Sag, Beibu Gulf Basin. Earth Sci. 2015, 40, 169-178. (In Chinese)

23. Liu, E.T.; Wang, H.; Li, Y.; Liao, Y.T.; Ma, Q.L.; Lin, Z.L. Control of transfer zone over sequences and depositional system in Fushan sag, Beibuwan Basin. J. China Univ. Pet. 2013, 37, 17-29. (In Chinese)

24. Vail, P.R.; Mitchum, R.M.; Thompson, S. Global cycles of relative changes of sea level. AAPG Bull. 1977, 26, 99-116.

25. Didyk, B.M.; Simoneit, B.R.T.; Brassell, S.C.; Eglinton, G. Organic geochemical indicators of palaeoenvironmental conditions of sedimentation. Nature 1978, 272, 216-222. [CrossRef]

26. Hughes, W.B.; Holba, A.G.; Dzou, L.I.P. The ratios of dibenzothiophene to phenanthrene and pristane to phytane as indicators of depositional environment and lithology of petroleum source rocks. Geochim. Cosmochim. Acta 1995, 59, 3581-3598. [CrossRef]

27. Xiao, H.; Li, M.J.; Yang, Z.; Zhu, Z.L. The distribution patterns and geochemical implication of C19-C23 tricyclic terpanes in source rocks and crude oils occurred in various depositional environment. Geochemica 2019, 48, 161-170. (In Chinese)

28. Ekweozor, C.; Strausz, O. Tricyclic terpanes in the Athabasca oil sands: Their geochemistry. In Advances in Organic Geochemistry; Wiley: New York, NY, USA, 1983; pp. 746-766.

29. Xiao, H.; Li, M.J.; Liu, J.G.; Mao, F.J.; Cheng, D.S.; Yang, Z. Oil-oil and oil-source rock correlations in the Muglad Basin, Sudan and South Sudan: New insights from molecular markers analyses. Mar. Pet. Geol. 2019, 103, 351-365. [CrossRef]

30. Aquito Neto, F.R.; Trendel, J.M.; Restlé, A.; Connan, J.; Albrecht, P. Occurrence and Formation of Tricyclic Terpanes in Sediments and Petroleums. In Advances in Organic Geochemistry; Wiley: Chichester, UK, 1983; pp. 659-667.

31. Tao, S.Z.; Wang, C.Y.; Du, J.G.; Liu, L.; Chen, Z. Geochemical application of tricyclic and tetracyclic terpanes biomarkers in crude oils of NW China. Mar. Pet. Geol. 2015, 67, 460-467. [CrossRef]

32. Zhu, Y.M. Geochemical characteristics of terrestrial oils of the Tarim Basin. Acta Sedimentol. Sin. 1997, 15, 26-30. (In Chinese)

33. Zumberge, J.E. Prediction of source rock characteristics based on terpane biomarkers in crude oils: A multivariate statistical approach. Geochim. Cosmochim. Acta 1987, 51, 1625-1637. [CrossRef]

34. Fu, J.; Chen, C.; Li, M.J.; Zhang, Z.T.; Long, Z.J.; Wang, T.G.; Lu, X.L. Petroleum charging history of Neogene reservoir in the Baiyun Sag, Pearl River Mouth Basin, South China sea. J. Pet. Sci. Eng. 2020, 190, 106945. [CrossRef]

35. Woodhouse, A.D.; Oung, J.N.; Philp, R.P.; Weston, R.J. Triterpanes and ring-A degraded triterpanes as biomarkers characteristic of Tertiary oils derived from predominantly higher plant sources. Org. Geochem. 1992, 18, 23-31. [CrossRef]

36. Samuel, O.J.; Kildahl-Andersen, G.; Nytoft, H.P.; Johansen, J.E.; Jones, M. Novel tricyclic and tetracyclic terpanes in Tertiary deltaic oils: Structural identification, origin and application to petroleum correlation. Org. Geochem. 2010, 41, 1326-1337. [CrossRef] 
37. Ma, N.; Hou, D.J.; Shi, H.S. Novel Tetracyclic Terpanes in Crude Oils and Source Rock Extracts in Pearl River Mouth Basin and Their Geological Significance. J. Earth Sci. 2014, 25, 713-718. [CrossRef]

38. Xiao, H.; Wang, T.G.; Li, M.J.; Fu, J.; Tang, Y.J.; Shi, S.B.; Yang, Z.; Lu, X.L. Occurrence and Distribution of Unusual Tri- and Tetracyclic Terpanes and Their Geochemical Significance in Some Paleogene Oils from China. Energy Fuels 2018, 32, 7393-7403. [CrossRef]

39. Boon, J.J.; Rijpstra, W.I.C.; De Lange, F.; De Leeuw, J.W.; Yoshioka, M.; Shimizu, Y. Black sea sterol-a molecular fossil for dinoflagellate blooms. Nature 1979, 277, 125-127. [CrossRef]

40. Whitehead, E.V. The stucture of petroleum pentaclanes. In Advances in Organic Geochemistry; Editions Technip: Paris, France, 1974; pp. 225-243.

41. Peters, K.E.; Moldowan, J.M. The Biomarker Guide: Interpreting Molecular Fossils in Petroleum and Ancient Sediments, 2nd ed.; Cambridge University Press: Cambridgeshire, UK, 2005; pp. 572-575.

42. Moldowan, J.M.; Dahl, J.; Huizinga, B.J.; Fago, F.J.; Hickey, L.J.; Peakman, T.M.; Taylor, D.W. The molecular fossil record of oleanane and its relation to angiosperms. Science 1994, 265, 768-771. [CrossRef]

43. Li, M.J.; Wang, T.G.; Liu, J.; Zhang, M.Z.; Lu, H.; Ma, Q.L.; Gao, L.H. The occurrence of oleananes in the Beibuwan Basin and its application to the study of maturity and oil-source rock correlation. Acta Geol. Sin. 2008, 82, 585-595.

44. Parnell, J. Potential of palaeofluid analysis for understanding oil charge history. In Frontiers in Geofluids; Wiley: New York, NY, USA, 2011.

45. Goldstein, R.H. Fluid inclusions in sedimentary and diagenetic systems. Lithos 2001, 55, 159-193. [CrossRef]

46. Bodnar, R.J. Revised equation and table for determining the freezing point depression of $\mathrm{H}_{2} \mathrm{O}-\mathrm{NaCl}$ solutions. Geochim. Cosmochim. Acta 1993, 57, 683-684. [CrossRef]

47. Tang, X.Y.; Hu, S.B.; Zhang, G.C.; Liang, J.S.; Yang, S.C.; Shen, H.L.; Rao, S.; Li, W.W. Geothermal characteristics and hydrocarbon accumulation of the northern marginal basins, South China Sea. Chin. J. Geophys. 2014, 57, 572-585.

48. Zhang, J.; Wang, J.Y. Deep geothermal characteristics of the northern continental margin of the South China Sea. Chin. Sci. Bull. 2000, 45, 1095-1100.

49. Kang, X.D.; Li, S.T.; Li, Y.L.; Hu, Z.L. Study on the geothermal characteristics and thermal history of Beibuwan Basin. J. Changchun Univ. Earth Sci. 1995, 25, 173-177. (In Chinese)

50. Zhao, S.J.; Wu, S.G.; Shi, H.S.; Dong, D.D.; Chen, R.X.; Wang, Y. Structures and dynamic mechanism related to the Dongsha movement at the northern margin of South China Sea. Progress Geophys. 2012, 27, 1008-1019. (In Chinese)

51. England, W.A.; Mackenzie, A.S.; Mann, D.M.; Quigley, T.M. The movement and entrapment of petroleum fluids in the subsurface. J. Geol. Soc. 1987, 144, 327-347. [CrossRef]

52. Leythaeuser, D.; Rückheim, J. Heterogeneity of oil composition within a reservoir as a reflection of accumulation history. Geochim. Cosmochim. Acta 1989, 53, 2119-2123. [CrossRef]

53. Horstad, I.; Larter, S.R.; Mills, N. Migration of hydrocarbons in the Tampen Spur area, Norwegian North Sea: A reservoir geochemical evaluation. Geol. Soc. Lond. Spec. Publ. 1995, 86, 159-183. [CrossRef]

54. Larter, S.; Bowler, B.F.J.; Li, M.; Chen, M.; Brincat, D.; Bennett, B.; Noke, K.; Donohoe, P.; Simmons, D.; Kohnen, M.; et al Molecular indicators of secondary oil migration distances. Nature 1996, 383, 593-597. [CrossRef]

55. Radke, M. Application of aromatic compounds as maturity indicators in source rocks and crude oils. Mar. Petrol. Geol. 1988, 5 , 224-236. [CrossRef]

56. Radke, M.; Welte, D.H.; Willsch, H. Distribution of alkylated aromatic hydrocarbons and dibenzothiophenes in rocks of the Upper Rhine Graben. Chem. Geol. 1991, 93, 325-341. [CrossRef]

57. Li, M.J.; Simoneit, B.R.T.; Zhong, N.N.; Fang, R.H. The distribution and origin of dimethyldibenzothiophenes in sediment extracts from the Liaohe Basin, East China. Org. Geochem. 2013, 65, 63-73. [CrossRef]

58. Li, M.J.; Zhong, N.N.; Shi, S.B.; Zhu, L.; Tang, Y.J. The origin of trimethyldibenzothiophenes and their application as maturity indicators in sediments from the Liaohe Basin, East China. Fuel 2013, 103, 299-307. [CrossRef]

59. Li, M.J.; Wang, T.G.; Shi, S.B.; Zhu, L.; Fang, R.H. Oil maturity assessment using maturity indicators based on methylated dibenzothiophenes. Petrol. Sci. 2014, 11, 234-246. [CrossRef]

60. Li, M.J.; Wang, T.G.; Zhong, N.N.; Zhang, W.B.; Sadik, A.; Li, H.B. Ternary diagram of fluorenes, dibenzothiophenes and dibenzofurans: Indicating depositional environment of crude oil source rocks. Energy Explor. Exploit. 2013, 31, 569-588. [CrossRef]

61. Wang, T.G.; He, F.Q.; Li, M.J.; Hou, Y.; Guo, S.Q. Alkyldibenzothiophenes: Molecular tracers for filling pathway in oil reservoirs. Chin. Sci. Bull. 2004, 49, 2399-2404. [CrossRef]

62. Radke, M.; Vriend, S.P.; Ramanampisoa, L.R. Alkyldibenzofurans in terrestrial rocks: Influence of organic facies and maturation. Geochim. Cosmochim. Acta 2000, 64, 275-286. [CrossRef]

63. Wang, N.; Li, M.J.; Liu, X.Q.; Hong, H.T.; Tian, X.W.; Yang, C.Y.; Shi, S.B.; Liu, P. Geo-chromatographic fractionation effect of methyldibenzofuran in dolomite reservoirs and its application in tracing oil filling pathways in the Sichuan Basin. Mar. Pet. Geol. 2020, 113, 104126. [CrossRef]

64. Luo, Q.; Pang, X.Q. Reservoir controlling mechanism and petroleum accumulation model for consequent fault and antithetic fault in Fushan Depression of Hainan area. Acta Pet. Sin. 2008, 29, 363-367. (In Chinese)

65. Zeng, B.; Li, M.J.; Wang, X.; Wang, F.Z.; Gong, C.L.; Lai, J.; Shi, Y. Source rock evaluation within a sequence stratigraphic framework of the Paleogene Liushagang Formation in the Fushan Depression, South China Sea. Geol. J. 2022. accepted. 